\title{
Global sea-level fluctuations during the Last Interglaciation (MIS 5e)
}

\author{
Paul J. Hearty ${ }^{\mathrm{a}, *}$, John T. Hollin ${ }^{\mathrm{b}}$, A. Conrad Neumann ${ }^{\mathrm{c}}$, \\ Michael J. O'Leary ${ }^{\mathrm{d}}$, Malcolm McCulloch ${ }^{\mathrm{e}}$ \\ ${ }^{a}$ School of Earth and Environmental Sciences, University of Wollongong, Wollongong, NSW 2522, Australia \\ ${ }^{\mathrm{b}}$ Institute of Arctic and Alpine Research, University of Colorado, Boulder, CO 80309, USA \\ ${ }^{\mathrm{c}}$ Marine Sciences Department, University of North Carolina, Chapel Hill, NC 27599-3300, USA \\ ${ }^{\mathrm{d}}$ Department of Environmental and Geographical Sciences, Manchester Metropolitan University, Manchester M1 5GD, UK \\ ${ }^{\mathrm{e}}$ Research School of Earth Sciences, The Australian University, Canberra, ACT 0000, Australia
}

Received 7 September 2006; received in revised form 11 May 2007; accepted 17 June 2007

\begin{abstract}
The geomorphology and morphostratigraphy of numerous worldwide sites reveal the relative movements of sea level during the peak of the Last Interglaciation (Marine Isotope Stage (MIS) 5e, assumed average duration between $130 \pm 2$ and $119 \pm 2 \mathrm{ka}$ ). Because sea level was higher than present, deposits are emergent, exposed, and widespread on many stable coastlines. Correlation with MIS 5e is facilitated by similar morphostratigraphic relationships, a low degree of diagenesis, uranium-thorium (U/Th) ages, and a global set of amino-acid racemization (AAR) data. This study integrates information from a large number of sites from tectonically stable areas including Bermuda, Bahamas, and Western Australia, and some that have experienced minor uplift $(\sim 2.5 \mathrm{~m} / 100 \mathrm{ka})$, including selected sites from the Mediterranean and Hawaii. Significant fluctuations during the highstand are evident at many MIS 5e sites, revealed from morphological, stratigraphic, and sedimentological evidence. Rounded and flat-topped curves derived only from reef tracts are incomplete and not representative of the entire interglacial story. Despite predictions of much different sea-level histories in Bermuda, the Bahamas, and Western Australia due to glacio- and hydro-isostatic effects, the rocks from these sites reveal a nearly identical record during the Last Interglaciation.

The Last Interglacial highstand is characterized by several defined sea-level intervals (SLIs) that include: (SLI\#1) post-glacial (MIS 6/5e Termination II) rise to above present before $130 \mathrm{ka}$; (SLI\#2) stability at +2 to $+3 \mathrm{~m}$ for the initial several thousand years $(\sim 130$ to $\sim 125 \mathrm{ka})$ during which fringing reefs were established and terrace morphology was imprinted along the coastlines; (SLI\#3) a brief fall to near or below present around $125 \mathrm{ka}$; (SLI\#4) a secondary rise to and through $\sim+3-4 \mathrm{~m}(\sim 124$ to $\sim 122 \mathrm{ka})$; followed by (SLI\#5) a brief period of instability $(\sim 120 \mathrm{ka})$ characterized by a rapid rise to between +6 to $+9 \mathrm{~m}$ during which multiple notches and benches were developed; and (SLI\#6) an apparently rapid descent of sea level into MIS 5d after $119 \mathrm{ka}$. U/Th ages are used to confirm the Last Interglacial age of the deposits, but unfortunately, in only two cases was it possible to corroborate the highstand subdivisions using radiometric ages.

Sea levels above or at present were relatively stable during much of early MIS 5e and the last 6-7 ka of MIS 1, encouraging a comparison between them. The geological evidence suggests that significant oceanographic and climatic changes occurred thereafter, midway through, and continuing through the end of MIS 5e. Fluctuating sea levels and a catastrophic termination of MIS 5e are linked to the instability of grounded and marine-based ice sheets, with the Greenland (GIS) and West Antarctic (WAIS) ice sheets being the most likely contributors. Late MIS 5e ice volume changes were accompanied by oceanographic reorganization and global ecological shifts, and provide one ominous scenario for a greenhouse world.
\end{abstract}

(C) 2007 Elsevier Ltd. All rights reserved.

\footnotetext{
*Corresponding author. Tel.: + 61747243110 .

E-mail address: paulh@uow.edu.au (P.J. Hearty).
}

\section{Introduction}

Because sea level rose above the present level during the peak of the Last Interglaciation ( = Marine Isotope Stage (MIS) 5e), stratigraphic and geomorphic evidence is abundant and widespread on many stable and uplifted 
coastlines of the world. Unfortunately, details of the eustatic history within this event remain confused and obscure due to (1) the lack of complete and definitive exposures from region to region; (2) incomplete or erroneous field observations and interpretations; (3) a general uncertainty arising from various dating and correlation methods and datable material; and (4) uncertainty created by the potential for and magnitude of regional glacio-hydroisostatic effects (e.g., Lambeck and Nakada, 1992).

Confronted with these uncertainties, we turn here to the most traditional, reliable, and fundamental principles of geomorphology, superposition, and morphostratigraphic succession at some of the most-studied global localities (Fig. 1). Field evidence, combined with independent confirmation of the age of the deposits through uranium series $(\mathrm{U} / \mathrm{Th})$ or amino-acid racemization (AAR) geochronology, offers an interdisciplinary approach to the study of sea-level history. A variety of field evidence is required to accurately interpret sea-level changes. For example, broad terraces and reef flats indicate periods of long-term stability of sea level, while notches and rubble benches reflect shortterm sea-level stillstands. Preservation of delicate coral structures on reef flats and well-preserved notch profiles suggest rapid regression of sea level; a slow retreat would reduce the corals to rubble and obscure sharp notches (Neumann and Hearty, 1996). Shallowing upward sequences, including the presence of terrestrial or soil deposits in shoreline aggradations, imply the retreat of sea level.

In principle, ice-equivalent, glacio-eustatic sea-level changes are most clearly defined on stable (Bermuda, Bahamas, and Western Australia) and slightly uplifted tectonic coastlines (i.e., Oahu, Hawaii; with an uplift rate of ca $2 \mathrm{~m} / 100 \mathrm{ka}$ ), although locations with higher rates of uplift are considered (Barbados at $20 \mathrm{~m} / 100 \mathrm{ka}$ ). Outcrops on stable coastlines reflect intervals of stability and interim shifts that constitute our composite sea-level model.

Based on averages of hundreds of high-quality U/Th ages from key sites, insolation-forcing and other considera- tions (Stearns, 1984; Chen et al., 1991; McCulloch and Esat, 2000; Edwards et al., 2003), we conclude from collective observations a broad highstand interval between $130 \pm 2$ and $119 \pm 2 \mathrm{ka}$. MIS 5e, the peak Last Interglacial (sensu stricto), corresponding to the conventional nomenclature of Eutyrrhenian (Mediterranean), Eemian (Europe), Rocky Bay Fm (Bermuda), Grotto Beach Fm (Bahamas), Sangamonian (North America), Waimanalo Fm (Hawaiian Islands), Bibra Fm (Shark Bay) and Rottnest and Tamala Limestone, Perth and Carnarvon basins (Western Australia), although we do not endorse some of these definitions. Geologic and dating studies have afforded an evolving picture of the MIS 5e sea-level history (Fig. 2). Most of these sea-level curves have been derived from relatively stable locations. Yet, common among many curves is evidence of instability, particularly during the latter half of the interglacial. References within each panel in Fig. 2 provide essential geologic and geochronologic details about the sites and the derivation of the curves.

Fundamental questions regarding the nature of MIS 5e sea level to be addressed in this paper include the following:

(1) Are multiple discrete sea-level positions recorded in the morphology, stratigraphy, and sedimentology of successions associated with MIS 5e?

(2) If so, what was the relative timing and amplitude of these intervals?

(3) Is it possible to subdivide the events of MIS 5e using state-of-the-art dating technology?

(4) Are studies using U/Th dating of exclusively coral reef terraces providing a complete and representative record of sea-level changes during MIS 5e?

(5) Were tectonic or glacio-hydro-isostatic effects great enough to produce far different sea-level histories from region to region?

(6) Is it possible to establish a consensus record of relative sea-level changes during the Last Interglaciation? and,

(7) Is it possible to suggest ice sources and underlying processes related to MIS 5e sea-level fluctuations?

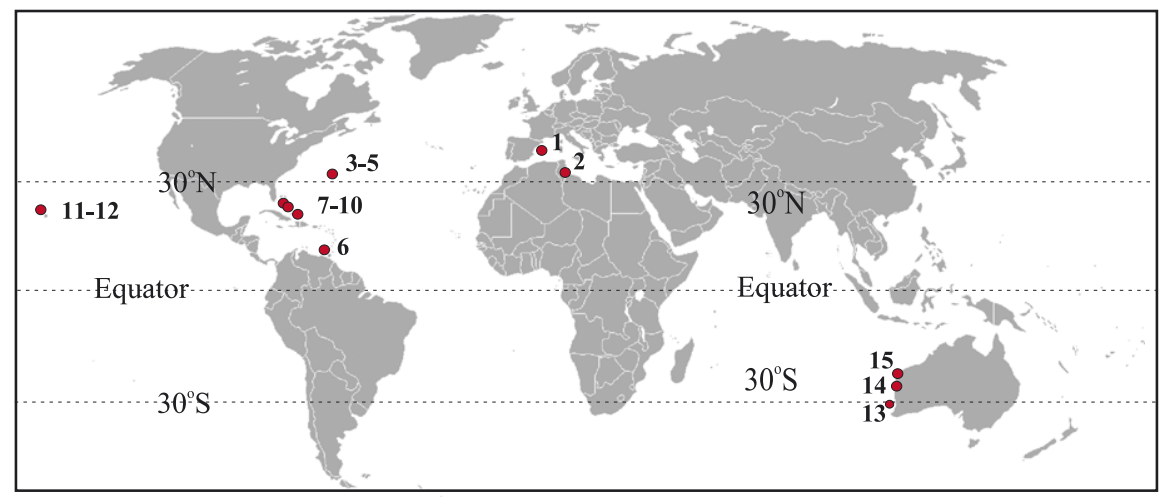

Fig. 1. Global map with numbered localities discussed in the text. 

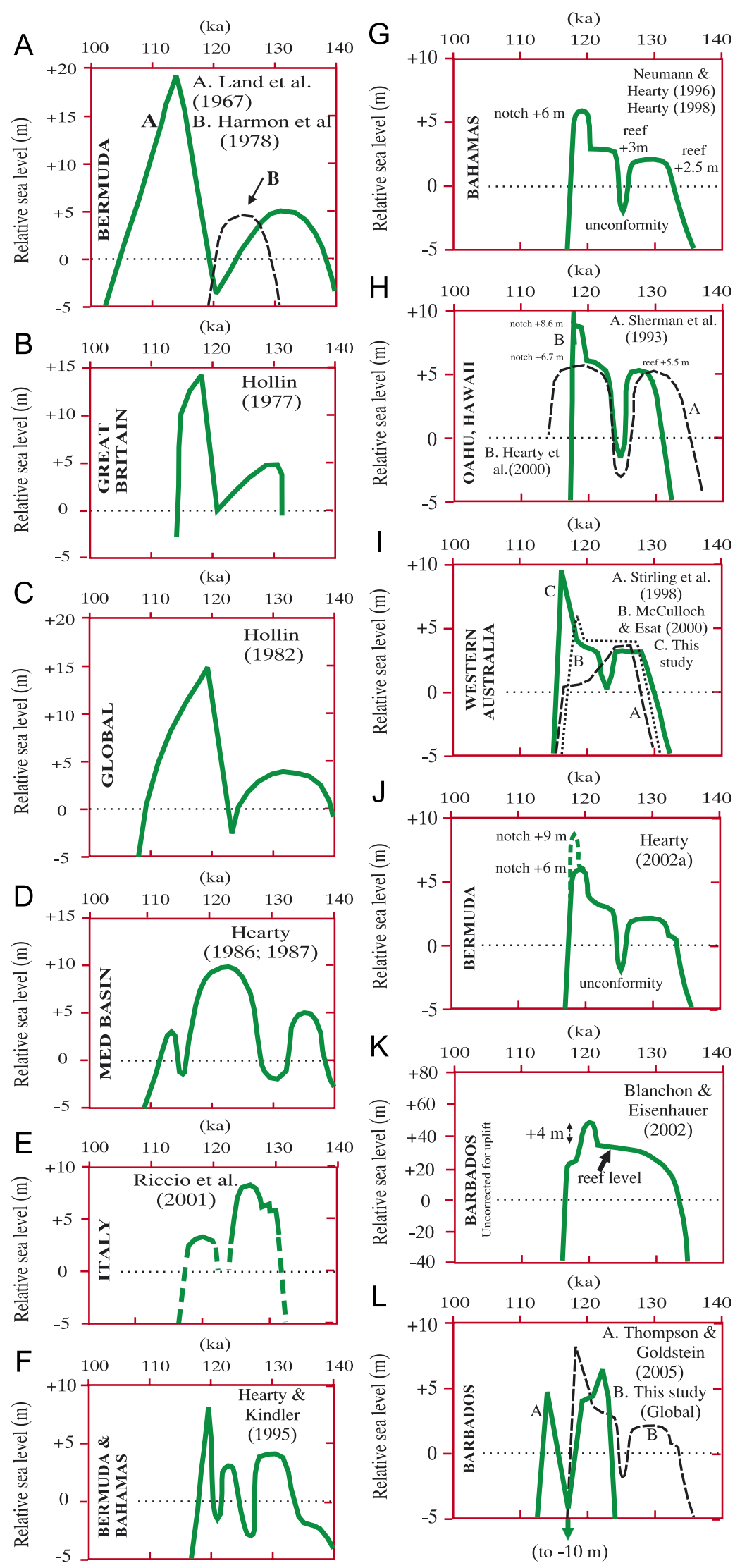

Fig. 2. A survey of published MIS 5e sea-level curves from stable (Bermuda, Bahamas, Western Australia), minimally uplifted (Hawaii, Mediterranean), and moderately tectonic (Barbados) localities. These accurately reproduced curves from several sea and ocean basins across tropical to temperate latitudes are derived primarily from geological studies. A curve generated from open-system U/Th transformations (Barbados, Panel L) is also included for comparison with the geological curves. The citations in each panel A through L provide background details of the stratigraphy, sedimentology, geomorphology, and geochronology underlying the interpretation of the curves. The curves highlight many important aspects of MIS 5e sea-level complexity across a global transect. Several rounded or box shaped sea-level curves are acknowledged but not illustrated as they do not support the complexity observed in the geologic record of MIS 5e sea level (Hollin, 1977, 1982). 


\section{Approach and methods}

\subsection{Field techniques}

Hundreds of Last Interglacial sites have been examined, stratigraphically logged, and dated with various methods by our group. This investigation selects the most complete and instructive of these sites for documentation of MIS 5e sea-level changes. With the exception of several sites from the Mediterranean Basin, all of the study sites from North Atlantic, Caribbean, North Pacific, and South Indian Ocean lie in the marginal tropics and subtropics between $20^{\circ}$ and $32^{\circ}$ north and south latitude. Nearly all of the deposits are fossiliferous and contain abundant (Mediterranean; Hawaii) to nearly pure (Bermuda, Bahamas, Western Australia) carbonate sediments. The tidal range at all sites is microtidal. Sites are presented in the text from east to west and Northern to Southern Hemisphere.

Standard field techniques were employed in each area where field teams identified the best and most complete exposures. Stratigraphic sections were measured, logged, photographed, and when possible, located by map coordinates, geographical landmarks, and/or GPS. Handlevel or theodolite surveys established the elevation of the deposits in question relative to mean sea level. Positive elevations in this study are expressed simply as "+" (as $+8 \mathrm{~m}$ ) for height above present mean sea level, and always include an assumed uncertainty of $\pm 1 \mathrm{~m}$ which takes into consideration measuring error, tidal, hydro-isostatic, and other minor local effects. Sample collections were made of all materials of interest including marine fossils, sediments, land fossils, soils, and paleosols. Samples were labelled and archived in plastic bags.

Field geology and geomorphology are essential tools in this integrated approach to interpret MIS 5e sea-level changes. Diligent "reading" of the rock record provides direct evidence of periods of sea-level stability and shifts during MIS 5e. From a combination of the coastal morphostratigraphy and precise measurement, the position of sea level at various intervals during the highstand can be determined. Given that hundreds of sites around the world are tied to MIS 5e through U/Th and AAR dating, it is practical now to compile and compare sea-level information from the best of these sites. Despite the enormous global MIS 5e database, in this investigation we limit ourselves to sites (1) of which we have a direct knowledge; (2) that have a detailed rock record and significant analytical foundation; and (3) that have a confirmed MIS $5 e$ age as determined by $\mathrm{U} / \mathrm{Th}$ and/or AAR correlation.

\subsubsection{Relative duration of SLIs based on field evidence}

We have determined from a considerable number of field studies (in cited references) that the relative duration of events is generally reflected in the magnitude of geomorphic imprint, outcrop extent, and volume of sediment deposited on the coastline. This is based on the principle that physical erosion, bioerosion, dissolution, sediment formation, transport, and deposition are time-dependent processes, such that the longer the event, the greater the physical expression of it. For example, broad reef flats and terraces reflect prolonged stable positions of sea level for thousands of years. In contrast, small notches, generally no more than 2-3 $\mathrm{m}$ deep, reflect brief pauses in sea level for hundreds of years (Neumann and Hearty, 1996).

\subsubsection{Sea level and coral reef terraces}

Many major studies have focused exclusively on coral reef terraces to interpret sea-level history (e.g., Dumas et al., 2006), but there are some important limitations to this approach. Hearty et al. (2007, p. 205) observed that "... coral reefs are less than ideal monitors of sea-level change; rather, they might be preferred as monitors of sealevel stability, as their response time and depositional tempo may be measured in many hundreds or thousands of years. Reefs may grow and flourish during slow rise of sea level. Once accommodation space is filled, vertical growth ceases, and only erosion and diagenesis of the reef substrate occurs until sea-level changes once more." Brief rises (of several metres) of sea level may inhibit the reef from catching up, and subsequent falls may leave little evidence of their passing. Important intervals of sea-level change may thus be lost or never recorded in the rocks. As a result, reefs are not a precise indicator of sea-level changes, particularly on tectonic coastlines where independent up and down movements of both sea level and tectonics are concurrent. One advantage, however, is that reefs are more amenable to dating. Sedimentary deposits and bioerosional notches, on the other hand, are potentially very precise and sensitive indicators of the sea-level movements, but are somewhat more difficult to date.

\subsubsection{Field evidence of past sea-level position}

A relatively precise measure of paleo-sea level is provided by the boundary between sub- and intertidal (beach) facies. The subtidal is characterised by high-angle, short co-set beds ("herringbone bedding"). Fig. 3A shows an excellent example of the transition between sub- and intertidal beds, and the approximate datum of MIS 5e paleo-sea level from Clifton Pier, New Providence Island, Bahamas (Hearty and Kindler, 1997). The position of sea level can be defined within a decimetre-wide zone around this boundary. Intertidal beach beds are generally planar, dipping $5-10^{\circ}$ seaward, and often contain fenestral porosity ("keystone vugs" etc., Dunham, 1970; Bain and Kindler, 1994) in fine to medium sand (Fig. 3B). As shoreline supratidal facies, coastal dunes may be interbedded with upper beach and storm deposits at their proximal edge and thus indicate the maximum position of sea level. Throughout the Bahamas, beach fenestrae are found at high levels up to $+30 \mathrm{~m}$ (Fig. 3C) in chevrons and on dunes interpreted as the result of effects of high seas and large waves (Hearty et al., 1998).

A less precise indicator are in situ articulated fossil bivalve molluscs and corals in living position. Acropora 

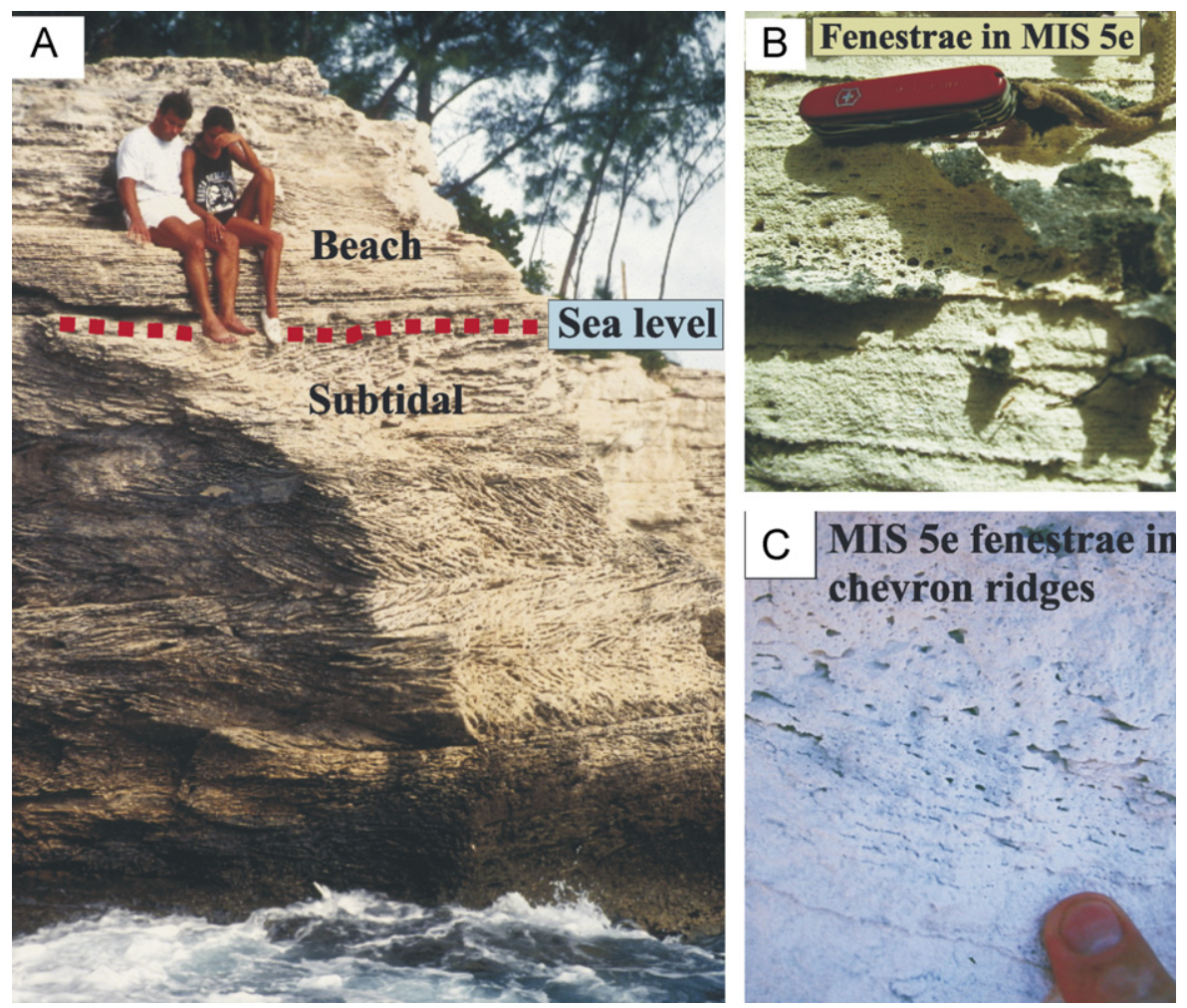

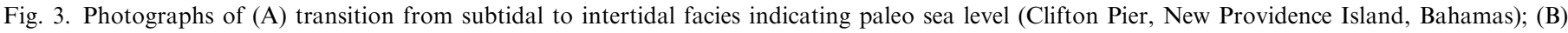

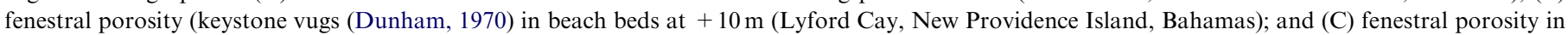
chevron ridges at $+30 \mathrm{~m}$ (North Eleuthera Island, Bahamas).

palmata may grow up to the mean low water mark, and thus have the potential to be a fairly precise indicator of a minimum sea level, but this species may also grow at $-5 \mathrm{~m}$ as well (Lighty et al., 1982; Chen et al., 1991; Blanchon and Eisenhauer, 2001). Deposits containing such biological indicators guarantee that sea level was higher than the highest in situ organisms, but how much higher is never a certainty.

\subsubsection{Bioerosional notches}

Notches might be considered as "incipient terraces" created during ephemeral stillstands of sea level, formed over perhaps several tens to a few hundred years (Neumann and Hearty, 1996). Rates of notch cutting and terrace planation have been experimentally calculated to be in the range of $0.5-\mathrm{mm} / \mathrm{yr}$ (Neumann, 1965; Playford, 1988; Spencer, 1992; Spencer and Viles, 2002). Empirical demonstrations indicate rates exceeding $2 \mathrm{~mm} / \mathrm{yr}$, although some actual rates may be higher by a factor of 2 to 3 (Hearty and Neumann, 2001) (Fig. 4A and B). Bioerosional notches are a precise indicator $( \pm$ several centimetres) of short-term (hundreds of years) sea-level positions (Fig. 4C). If sea level remains in the same position for more than several hundred years, the notch is more deeply cut, eventually causing the visor to collapse. Normally it is impossible to date a morphological void; however, in some fortuitous cases, relict borings or encrustations of corals, serpulids, or other in situ fossils may be present. Further, notches may be back filled with datable materials (e.g., Watch Hill Park, Bermuda, Hearty, 2002a), potentially providing a minimum age of the feature.

\subsubsection{Petrographic considerations}

Grain characteristics including size (cobbles, pebbles, sand, silt, clays), composition (aragonite/calcite percentage, bioclasts, shells), angularity (poorly or well rounded, spherical or not), sorting (shell lenses, graded beds, etc.), and trace fossils can all be useful in identifying subtidal, beach, and aeolian environments. If initial cementation occurs soon after the deposition of coastal sediments, this transition can be used as an indicator of sustained submergence in marine phreatic water (Hearty et al., 1999).

\subsection{Geochronology}

\subsubsection{U/Th dating}

$\mathrm{U} / \mathrm{Th}$ dating is the most reliable method for confirmation of the age of coastal deposits of late Pleistocene age. The method is most effective if pristine, in situ corals in stratigraphic context are used for dating, thus excluding most temperate sites above $35^{\circ}$ latitude and those lacking aragonitic corals. Past efforts to date molluscs with U/Th have been largely unproductive and criticized (Kaufman et al., 1971; Hoang and Hearty, 1989; Kaufman et al., 1996), and have led to controversial sea-level histories. 


\section{Modern and fossil notches}
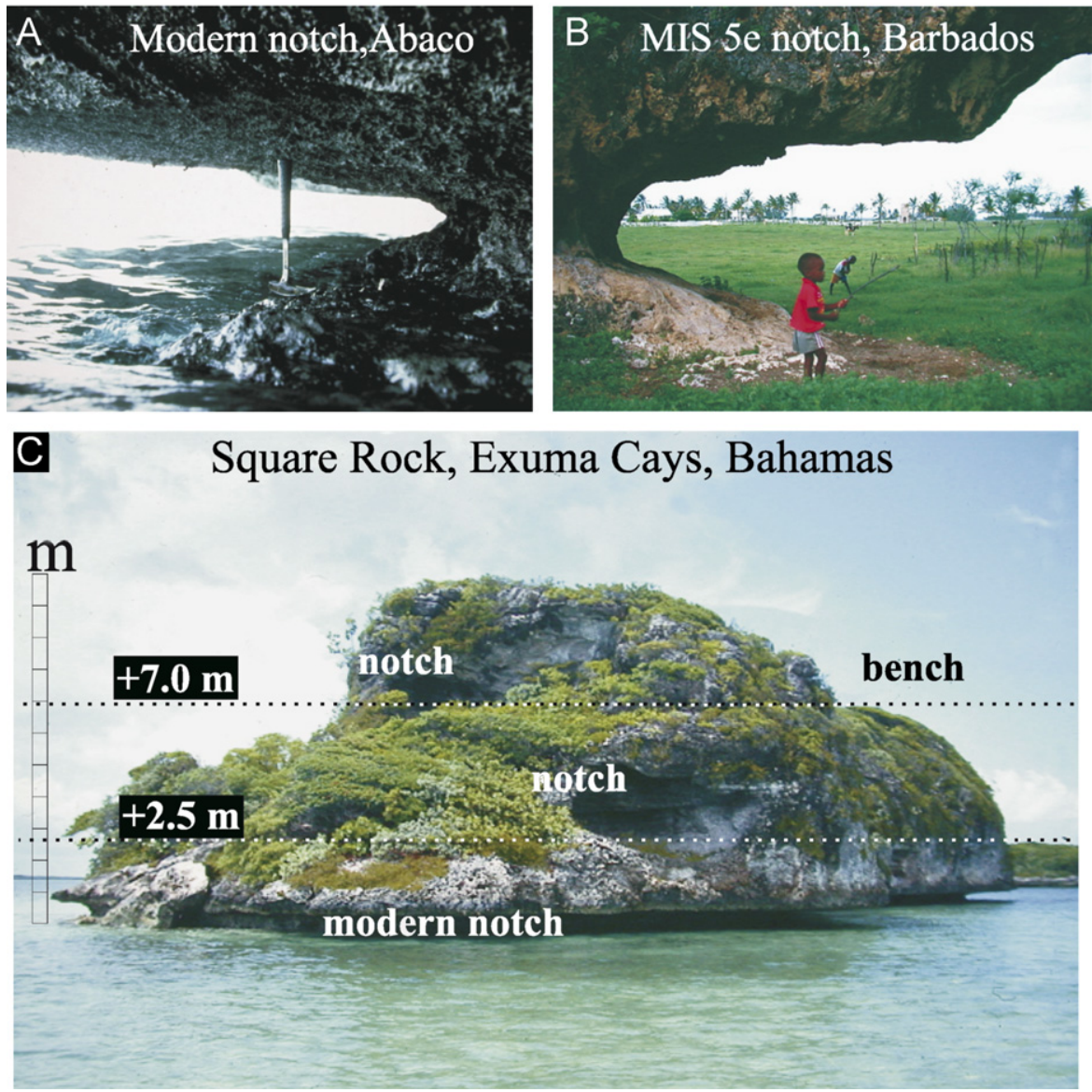

Fig. 4. (A) Modern notch in middle Pleistocene rocks (Abaco Island, Bahamas); (B) MIS 5e fossil notch in fallen boulder (northwest Barbados); and (C) elevated notches in middle Pleistocene eolianite etched by MIS 5e sea-level stands at +2.5 and $+7 \mathrm{~m}$ (Square Rock, Exuma Cays, Bahamas).

Therefore, no ages or sea-level curves derived from molluscs are used in this study.

Over the past several decades, measurement of $\mathrm{U} / \mathrm{Th}$ isotopes has progressed from $\alpha$-counting $(\alpha-\mathrm{U} / \mathrm{Th})$, to thermal ionization mass spectrometry (TIMS) (Edwards et al., 1987), and most recently, multi-collector, inductively coupled plasma mass spectrometry (MC-ICPMS) (Andersen, 2004), and laser-ablation MC-ICPMS (Eggins et al., 2005). We have determined a considerable number of new MC-ICPMS ages (O'Leary, 2007) (Table 1). All of our samples were collected in a detailed stratigraphic context, relative to early and late sedimentary phases of MIS 5e. Corals were screened for potential open-system chemical and isotopic exchange (reliable dates in bold, Table 1), following the procedures of earlier workers (Chen et al., 1991; Stirling et al., 1995, 1998; Robinson et al., 2004). However, as the focus of this paper is not $\mathrm{U} / \mathrm{Th}$ dating, but geomorphology and morphostratigraphy, we do not endeavour to explain previous $\mathrm{U} / \mathrm{Th}$ studies and data. Rather, the primary function of $U / T h$ coral ages is to confirm a correlation with Last Interglacial. In cases where stratigraphic context and sample quality are optimal, it is important to test the method to determine if the stratigraphic succession can be confirmed. Previously,
$\mathrm{U} / \mathrm{Th}$ ages were used for calibration of AAR ratios in Bermuda (Harmon et al., 1978, 1981, 1983; Ludwig et al., 1996; Muhs et al., 2002), the Bahamas (Chen et al., 1991); the Mediterranean (Hearty, 1986; Hearty et al., 1986), Hawaii (Muhs and Szabo, 1994; Szabo et al., 1994), and Australia (Stirling et al., 1995, 1998; McCulloch and Esat, 2000; O'Leary, 2007). Within the temporal framework of the highstand $(130 \pm 2$ and $119 \pm 2 \mathrm{ka})$ relative ages of sealevel movements can be reasonably estimated on the basis of geological factors within MIS 5e.

\subsubsection{Amino-acid racemization ( $A A R$ )}

The AAR method is based on the intraconversion of D- and L-enantiomers (in this case D-alloisoleucine/ L-isoleucine $=\mathrm{A} / \mathrm{I}$ ) from fossil material. The $\mathrm{A} / \mathrm{I}$ epimerization reaction proceeds over time at a rate controlled by temperature. Thus, within areas with similar temperature histories, differences in $\mathrm{A} / \mathrm{I}$ from well-preserved materials reflect primarily age differences. An independent calibration with $\mathrm{U} / \mathrm{Th}$ ages is required between areas and regions to correct for differing climate histories. Studies from the Mediterranean (Hearty et al., 1986), Bermuda (Hearty et al., 1992), Bahamas (Hearty and Kaufman, 2000), Hawaii (Hearty et al., 2000), and 
Table 1

MC-ICPMS ages from sites in Bahamas, Hawaii, and Western Australia discussed in this study

\begin{tabular}{|c|c|c|c|c|c|c|c|c|c|c|c|c|}
\hline Sample ID & $\mathrm{U}^{\mathrm{a}} \mathrm{ppm}$ & ${ }^{230} \mathrm{Th}^{\mathrm{b}} \mathrm{ppt}$ & ${ }^{232} \mathrm{Th}^{\mathrm{c}} \mathrm{ppb}$ & $\delta^{234} U^{d}$ & $\pm 2 \sigma$ & ${ }^{230} \mathrm{Th} /{ }^{238} \mathrm{U}^{\mathrm{e}}$ & $\pm 2 \sigma$ & ${ }^{230} \mathrm{Th} /{ }^{232} \mathrm{Th}$ & $\operatorname{Age}^{\mathrm{f}}(\mathrm{ka})$ & $\pm 2 \sigma(\mathrm{ka})$ & Initial $\delta^{234} \mathrm{U}^{\mathrm{g}}$ & $\pm 2 \sigma$ \\
\hline \multicolumn{13}{|c|}{ Site 8. Upper reef, Hole in the Wall, Abaco, Bahamas } \\
\hline AHW2d 1 & 3.13 & 37.76 & 0.18 & 111.82 & 0.76 & 0.7431 & 0.0247 & 38459 & 116.79 & 6.83 & 155.71 & 3.08 \\
\hline AHW2d 2 & 2.99 & 37.32 & 0.75 & 115.73 & 0.91 & 0.7681 & 0.0039 & 9304 & 123.01 & 1.14 & 164.02 & 1.28 \\
\hline AHW2d 3 & 2.05 & 25.03 & 0.08 & 105.66 & 1.16 & 0.7518 & 0.0016 & 58416 & 120.58 & 0.52 & 148.72 & 1.51 \\
\hline \multicolumn{13}{|c|}{ Site 8. Lower reef, Hole in the Wall, Abaco, Bahamas } \\
\hline AWH2d_2 & 1.83 & 23.09 & 0.30 & 112.97 & 1.97 & 0.7787 & 0.012 & 14885.0 & 127.00 & 3.5 & 161.8 & 3 \\
\hline \multicolumn{13}{|c|}{ Site 11. Upper reef, Mokapu } \\
\hline OKP 2c & 2.45 & 32.13 & 24.16 & 111.50 & 0.81 & 0.7910 & 0.0013 & 273 & 130.90 & 0.46 & 161.59 & 1.07 \\
\hline OKP 3c & 2.48 & 31.83 & 4.44 & 108.39 & 0.79 & 0.7887 & 0.0015 & 18865 & 130.97 & 0.49 & 157.13 & 1.05 \\
\hline \multicolumn{13}{|c|}{ Site 11. Lower reef, Mokapu } \\
\hline OKP $2 \mathrm{a}$ & 2.22 & 28.78 & 0.13 & 119.63 & 0.87 & 0.7987 & 0.0012 & 53242 & 131.24 & 0.41 & 173.56 & 1.16 \\
\hline \multicolumn{13}{|c|}{ Site 12. Upper reef, Makua Valley (Kaena Point south) } \\
\hline OMU1b & 2.18 & 27.04 & 0.09 & 109.03 & 2.32 & 0.7654 & 0.004 & 58442.5 & 123.80 & 1.3 & 154.8 & 2.95 \\
\hline \multicolumn{13}{|c|}{ Site 12. Upper reef, Kahe Beach State Park } \\
\hline $\mathrm{OHE} \mathrm{1c}$ & 2.51 & 30.74 & 0.33 & 114.85 & 0.71 & 0.7547 & 0.0022 & 20917 & 119.37 & 0.57 & 161.11 & 0.93 \\
\hline \multicolumn{13}{|c|}{ Site 12. Corals at $+4 m$ in Lower reef, Kahe Beach State Park } \\
\hline OHE 2a 1 & 2.28 & 27.38 & 0.17 & 115.21 & 1.55 & 0.7403 & 0.0042 & 38643 & 115.35 & 1.15 & 159.77 & 2.01 \\
\hline OHE 2a 2 & 2.20 & 26.82 & 0.06 & 111.94 & 1.23 & 0.7487 & 0.0031 & 135934 & 118.31 & 0.89 & 156.56 & 1.59 \\
\hline \multicolumn{13}{|c|}{ Site 14. Cape Cuvier, upper coralgal rim } \\
\hline LCV_1e_2 & 2.20 & 28.28 & 11.63 & 111.69 & 0.63 & 0.7874 & 0.0011 & 454 & 129.74 & 0.37 & 161.34 & 0.79 \\
\hline LCV_1e_3 & 3.35 & 44.07 & 0.15 & 114.10 & 0.84 & 0.8091 & 0.0019 & 54759 & 135.98 & 0.68 & 167.76 & 1.17 \\
\hline LCV_2e_1 & 3.17 & 42.81 & 0.10 & 133.64 & 0.76 & 0.8309 & 0.0027 & 78065 & 137.73 & 0.90 & 197.47 & 1.09 \\
\hline $\mathrm{LCV} \_2 \mathrm{e} \_3$ & 3.88 & 50.91 & 1.48 & 130.34 & 0.80 & 0.8076 & 0.0029 & 6441 & 131.25 & 0.87 & 189.10 & 1.15 \\
\hline LCV_2e_4 & 4.37 & 56.01 & 0.75 & 126.80 & 0.84 & 0.7887 & 0.0018 & 13939 & 126.46 & 0.53 & 181.48 & 1.10 \\
\hline \multicolumn{13}{|c|}{ Site $\overline{14} . \bar{L}$ Lower $+4 m$ reef flat, Cape Cuvier proper } \\
\hline LCV 6.5 & 2.21 & 28.88 & 0.06 & 124.98 & 0.68 & 0.8021 & 0.0019 & 89622 & 130.93 & 0.59 & 181.14 & 0.90 \\
\hline LCV7 T1 & 2.69 & 34.21 & 0.16 & 128.60 & 1.03 & 0.7837 & 0.0021 & 39635 & 124.57 & 0.61 & 183.07 & 1.41 \\
\hline LCV7 T2 & 3.14 & 40.36 & 0.13 & 119.20 & 1.02 & 0.7917 & 0.0023 & 56496 & 129.18 & 0.73 & 171.92 & 1.38 \\
\hline LCV7 T3 & 3.22 & 40.83 & 0.75 & 112.43 & 1.01 & 0.7803 & 0.0017 & 10213 & 125.02 & 0.53 & 174.50 & 1.31 \\
\hline LCV7e_3c & 3.44 & 42.37 & 0.31 & 124.62 & 1.04 & 0.7577 & 0.0024 & 25669 & 118.13 & 0.66 & 174.19 & 1.33 \\
\hline LCV3e_2a & 3.13 & 42.64 & 0.08 & 143.32 & 0.85 & 0.8384 & 0.0028 & 94188 & 137.53 & 0.88 & 211.66 & 1.20 \\
\hline LVC3e_2b & 3.16 & 42.17 & 0.10 & 139.27 & 1.21 & 0.8208 & 0.0026 & 76512 & 133.06 & 0.86 & 203.08 & 1.68 \\
\hline \multicolumn{13}{|c|}{ Coral fragment from $+10 \mathrm{~m}$ beach under boulder, near Korean Star, $14 \mathrm{~km} N$ of Cape Cuvier } \\
\hline LCC1f_C & 2.32 & 35.88 & 13.83 & 123.24 & 1.19 & 0.9540 & 0.006 & 486.4 & 191.70 & 3.2 & 212.2 & 2.4 \\
\hline \multicolumn{13}{|c|}{ Site 15. Coral rubble at $+8 m$, Cape Range (“Jacobesz Rd") } \\
\hline NJZ1d 1 & 2.02 & 25.26 & 5.10 & 108.60 & 1.22 & 0.7675 & 0.0022 & 929 & 124.47 & 0.70 & 154.55 & 1.58 \\
\hline NJZ1d 2 & 2.14 & 26.58 & 0.79 & 108.52 & 0.81 & 0.7653 & 0.0020 & 6291 & 123.84 & 0.61 & 154.16 & 1.04 \\
\hline
\end{tabular}

Ages considered to be strictly reliable are in bold.

${ }^{\mathrm{a}}$ Uranium concentrations are measured in part per million (ppm) equivalent to $\mathrm{ng} / \mathrm{g}$.

${ }^{\mathrm{b} 230} \mathrm{Th}$ concentrations measured in parts per trillion $(\mathrm{ppt})$ equivalent to $\mathrm{fg} / \mathrm{g}$.

${ }^{\mathrm{c} 232} \mathrm{Th}$ concentrations measured in parts per billion $(\mathrm{ppb})$ equivalent to $\mathrm{pg} / \mathrm{g}$.

${ }^{\mathrm{d}} \delta^{234} \mathrm{U}=\left\{\left[\left({ }^{234} \mathrm{U} /{ }^{238} \mathrm{U}\right) /\left({ }^{234} \mathrm{U} /{ }^{238} \mathrm{U}\right)_{\mathrm{eq}}\right]-1\right\} \times 103$. $\left(234 \mathrm{U} /{ }^{238} \mathrm{U}\right)_{\mathrm{eq}}$ is the atomic ratio at secular equilibrium and is equal to $\lambda_{238} / \lambda_{234}=5.4891 \times 10^{-5}$, where $\lambda_{238}$ and $\lambda_{234}$ are the decay constants for ${ }^{238} \mathrm{U}$ and ${ }^{234} \mathrm{U}$, respectively, adopting half-lives of Cheng et al. (1998, 2000).

${ }_{\mathrm{e}}\left[{ }^{230} \mathrm{Th} /{ }^{238} \mathrm{U}\right]_{\text {act }}=\left({ }^{230} \mathrm{Th} /{ }^{238} \mathrm{U}\right) /\left(\lambda_{238} / \lambda_{230}\right)$.

${ }^{\mathrm{f}} \mathrm{U}$-series ages are calculated iteratively using.

$1-\left[\frac{{ }^{230} \mathrm{Th}}{{ }^{238} \mathrm{U}}\right]_{\text {act }}=\mathrm{e}^{-\lambda_{230} T}\left(\frac{d^{234} \mathrm{U}(0)}{1000}\right)\left(\frac{\lambda_{230}}{\lambda_{230}-\lambda_{234}}\right)\left(1-\mathrm{e}^{\left(\lambda_{234}-\lambda_{230}\right) T}\right)$,

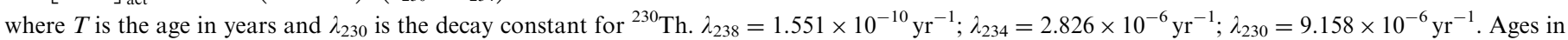
bold type are strictly reliable.

${ }^{\mathrm{g}}$ The initial value is given by $\delta^{234} \mathrm{U}_{\mathrm{i}}=\delta^{234} \mathrm{Ue}^{\lambda_{234} T}$ where $T$ is the age in years.

Australia (Murray-Wallace and Belperio, 1991; MurrayWallace et al., 2001; Hearty, 2003; Hearty et al., 2004) provide the framework and database for this application to Last Interglacial shorelines. Recent advances in whole-rock (WR) aminostratigraphy using oolite and bioclastic sedi- ments now allow beach and eolianite deposits to be directly dated. A/I can independently provide an index of the relative ages of fossils or sediments, and a means to correlate deposits over long distances on this basis (Hearty and Kaufman, 2000). At numerous deposits, however, both 
$\mathrm{A} / \mathrm{I}$ and radiometric ages are available, making it possible to confirm correlations, 'calibrate' $\mathrm{A} / \mathrm{I}$ ratios, and provide numeric age estimates from modal classes of $\mathrm{A} / \mathrm{I}$.

Previous and new results from marine shells or WR from widespread sites around the world are summarised in Table 2. The mean or range of ratios fit well into global MIS 5e gradients of $\mathrm{A} / \mathrm{I}$ versus mean annual temperature and/or latitude (Fig. 5).

\section{Results}

\subsection{Field identification of MIS 5e sea-level deposits}

MIS 5e highstand deposits are recognized on the basis of a variety of field evidence. On stable or mildly uplifted sedimentary coastlines, MIS 5e deposits are either being actively buried by, eroded by, or morphostratigraphically

Table 2

Marine shell and whole-rock ratios from correlated and U/Th calibrated MIS 5e deposits

\begin{tabular}{|c|c|c|c|c|}
\hline (Site \# in text) region, locality & References & $\begin{array}{l}\text { MIS } 5 \text { e A/I ratios: Genus }(\mathrm{G}, \mathrm{A} \text {, } \\
\mathrm{M}, \mathrm{T})^{\mathrm{a}} \text { or whole-rock (WR) }\end{array}$ & $\begin{array}{l}125 \mathrm{ka} \\
\sqrt{ }=\mathrm{yes}\end{array}$ & Lat. $\left({ }^{\circ} \mathrm{N}\right.$ or $\left.{ }^{\circ} \mathrm{S}\right)$ \\
\hline
\end{tabular}

\section{Mediterranean}

(1) Tuscany, N. Lazio, Italy

(1) Mar Piccolo, Italy

(1) Campo de Tiro, Mallorca

(1) Calamosca, Sardinia

(1) Almeria, Spain

(2) Hergla, Tunisia

Bermuda-Barbados

(3/4) Grape Bay

(3/5) Spencer's Pt.

(6) Christ Church, Barbados

\section{Bahamas}

(7) Bahamas

(8) Hole in the Wall, Abaco

(9) Cockburn Town, San

Salvador Island

(10) Lyford Cay, New Providence

Eleuthera

Long Island

Acklins Island

Mayaguana Island

Inagua Island

Quintana Roo, Mex.

SE US Coastal Plain

Myrtle Beach, SC

Charleston SC $19^{\circ} \mathrm{C}$

North Florida $20.9^{\circ} \mathrm{C}$

Mid Florida $22^{\circ} \mathrm{C}$

Jupiter, FL $22^{\circ} \mathrm{C}$

South Florida $23.5^{\circ} \mathrm{C}$

Hawaiian Islands

Makawehi, Kauai

(11) East Oahu Mokapu

(12) West Oahu Kahe Beach;

Makua, Barbers Point
Hearty and Dai Pra (1986)

Hearty and Dai Pra (1992)

Hearty (1987)

Ulzega and Hearty (1986)

Hearty et al. (1987)

Miller et al. (1986), Hearty (1986)

Harmon et al. (1983),

Muhs et al. (2002),

Hearty et al., (1992),

Meischner et al. (1995)

Hearty (2002a)

Hearty (2002a)

Rendezvous Hill (RH)

Maxwell (Max)

$\mathrm{Ku}$ et al. (1990), Hearty, unpublished

Hearty and Kaufman (2000)

This study

Chen et al. (1991), Hearty and Kindler (1993b)

Muhs et al. (1990)

Hearty and Kindler (1997)

Hearty (1998)

Hearty and Kaufman (2000)

Hearty and Kaufman (2000)

Hearty and Kaufman (2000)

Chen et al. (1991)

Hearty and Kaufman (2000)

Hearty, Unpublished

Hollin and Hearty (1990)

Hollin and Hearty (1990)

Mitterer (1974, 1975)

Mitterer (1974, 1975)

Hearty, Unpublished.

Mitterer (1974, 1975)

Hearty et al. (2000)

Muhs and Szabo (1994), Szabo et al.

(1994), Hearty et al. (2005)

Sherman et al. (1993)

Hearty et al. (2000)

This study

$$
\begin{aligned}
& \text { G } 0.39 \pm 0.02(39) \\
& \text { G } 0.39 \pm 0.03(56) \\
& \text { G } 0.41 \pm 0.04(38) \\
& \text { G } 0.43 \pm 0.03(11) \\
& \text { G } 0.49 \pm 0.05(8) \\
& \text { G } 0.48 \pm 0.04(42)
\end{aligned}
$$

WR $0.30 \pm 0.02(18)$

WR $0.40 \pm 0.02(15)$

G $0.58 \pm 0.04(10)$

G $0.70 \pm 0.03$ (7)

WR 0.22

WR $0.37 \pm 0.02$ (4) (RH)

WR $0.48 \pm 0.04$ (4) (Max)

Cline of WR ratios from north to south

WR $0.36 \pm 0.02$ (2)

WR $0.40 \pm 0.04(18)$ G 0.80 (1)

WR $0.36 \pm 0.02$ (5)

WR $0.38 \pm 0.02(12)$

WR $0.43 \pm 0.02(10)$

WR $0.44 \pm 0.06$ (4)

WR $0.45 \pm 0.01$ (2)

WR $0.48 \pm 0.02$ (4)

WR $0.49 \pm 0.03(4)$

range

A $0.44 \pm 0.05$ (29)

A $0.51 \pm 0.04$ (9)

M $0.43 \pm 0.02$

M $0.56 \pm 0.04$

G $0.76 \pm 0.01$ (2)

M $0.71 \pm 0.04$

WR $0.46 \pm 0.04$ (12)

WR 0.48 (2)

WR 0.55 (2)

WR $0.48 \pm 0.02$ (8) 
Table 2 (continued)

\begin{tabular}{|c|c|c|c|c|}
\hline (Site \# in text) region, locality & References & $\begin{array}{l}\text { MIS 5e A/I ratios: Genus }(\mathrm{G}, \mathrm{A} \text {, } \\
\mathrm{M}, \mathrm{T})^{\mathrm{a}} \text { or whole-rock (WR) }\end{array}$ & $\begin{array}{l}125 \mathrm{ka} \\
\sqrt{ }=\text { yes }\end{array}$ & Lat. ( \\
\hline \multicolumn{5}{|l|}{ Western and South Australia } \\
\hline Coorong Peninsula & Unpublished & WR $0.35 \pm 0.02(12)$ & $\sqrt{ }$ & 37.1 \\
\hline Foul; Hamelin Bays & Unpublished & WR $0.26 \pm 0.02(6)$ & $\sqrt{ }$ & 34.3 \\
\hline (13) Perth-Rottnest I & Hearty (2003) & WR $0.33 \pm 0.03(18)$ & $\sqrt{ }$ & 32.0 \\
\hline Leander Point & Stirling et al. $(1995,1998)$, this study & WR $0.35 \pm 0.02(4)$ & $\sqrt{ }$ & 29.3 \\
\hline Cape Burney & This study & WR $0.50 \pm 0.02(6)$ & $\sqrt{ }$ & 28.8 \\
\hline (14) Cape Cuvier; Shark Bay & $\begin{array}{l}\text { Denman and van de Graaff (1976), This } \\
\text { study }\end{array}$ & $\begin{array}{l}\text { WR } 0.48 \\
\text { WR } 0.56 \pm 0.08(20)\end{array}$ & $\sqrt{ }$ & $\begin{array}{l}24.3 \\
26.0\end{array}$ \\
\hline (15) Cape Range, Ningaloo Reef & Kendrick et al. (1991), This study & WR $0.57 \pm 0.05$ & $\sqrt{ }$ & 22.1 \\
\hline \multicolumn{5}{|c|}{ Papua New Guinea, Huon Peninsula } \\
\hline Papua New Guinea & $\begin{array}{l}\text { Aharon et al. (1980) } \\
\text { Hearty and Aharon (1988) }\end{array}$ & T $1.08 \pm 0.08$ (9) & $\sqrt{ }$ & 6.5 \\
\hline
\end{tabular}

Study sites or areas discussed in detail in the text are identified numerically in column 1 . The " $\sqrt{ }$ " in column 4 indicates the MIS 5 e age of the site is confirmed by U/Th ages. See site references for details of geomorphology, stratigraphy, sedimentology, and dating.

Refer to Table 1 or O'Leary (2007) for MC-ICPMS dates produced during this study.

${ }^{\mathrm{a}}$ Genus: $\mathrm{G}=$ Glycymeris; $\mathrm{A}=$ Anadara $; \mathrm{M}=$ Mercenaria $; \mathrm{T}=$ Tridacna.

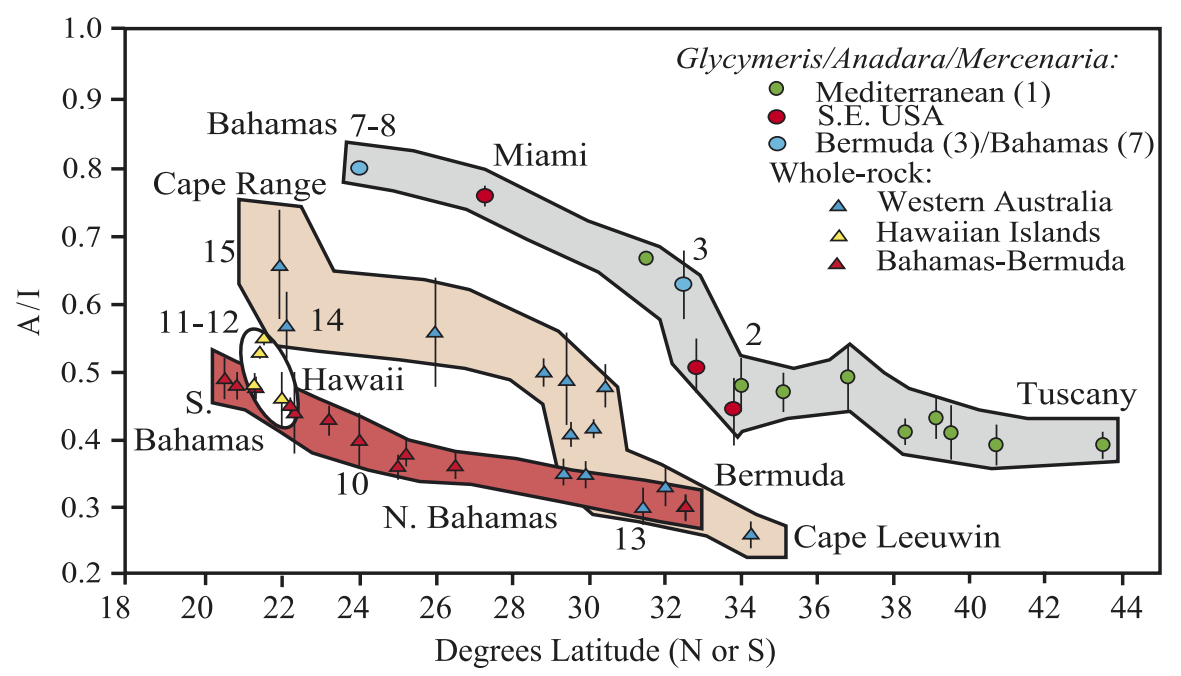

Fig. 5. A/I versus latitude gradients for moderate-rate epimerization in molluscs (Glycymeris, Anadara, and Mercenaria, Tridacna) and whole-rock samples from sites in Table 2. The respective mollusc and whole-rock curves, generated from hundreds of sites and samples, reflect warmer thermal histories at lower latitude, as well as the steeper gradients within particular latitudes (e.g., around $30^{\circ}$ in WR of Western Australia, and $33^{\circ}$ in the composite molluscs curve).

positioned immediately inland of Holocene and modern beach and dune deposits. MIS 5e coastal dune ridges are commonly volumetrically larger than those immediately preceding or succeeding the highstand. In most observed cases, the weight percentage of carbonate sediments are relatively more abundant in MIS 5e deposits than immediately older or younger shore deposits, even at latitudes beyond the subtropics (Kindler et al., 1997), implying warmer ocean conditions. Carbonate-rich marine or aeolian sediments in particular, are generally in a state of early or moderate diagenetic alteration relative to nearly pristine Holocene counterparts but significantly less altered than middle or early Pleistocene deposits (Land et al., 1967; Kindler and Hearty, 1996; Hearty, 1998). Soils capping carbonate-rich MIS 5e deposits are sandy and display colours in the yellowish brown (e.g., 10YR 7/8) to reddish brown (e.g., 5YR 5/4) range (Munsell, 2001), compared with older middle Pleistocene soils which have progressed to red (e.g., 2.5YR 4-5/8) to dark red (e.g., 10R 3/6) hues (e.g., similar methods applied in Hearty and Kindler, 1997; Hearty, 1998; Hearty et al., 2000).

MIS $5 \mathrm{e}$ is also widely recognized as a warmer-thanpresent interglaciation on the basis of the abundance of extralimital species. For example, the "Senegalese Fauna" (Nicklés, 1950; Bonifay and Mars, 1959) invaded the Mediterranean during MIS 5e. Similarly, numerous MIS 5e sites along the Atlantic and Pacific coasts of North America, Hawaii, and Western Australia (Kendrick et al., 
1991; Muhs et al., 2002) contain thermophilous faunal elements unlike those of today. Global oceanographic currents conveying warm oceanic waters from the tropics to higher latitudes may be altered dramatically, particularly during climate shifts within or between interglacials and glacials. Such changes have been documented in the Gulf Stream (Adkins et al., 1997; Broecker, 1997) and the Leeuwin Current (Cann and Clarke, 1993; McGowran et al., 1997).

\subsection{MIS 5e notches}

Notches play an important role in studies of MIS 5e sealevel history. Although notches can form by physical abrasion at sea level, bioerosional notches formed in older and more indurated limestone are most common. Context generally defines which notches are of Holocene age by geomorphic sharpness and proximity to present sea level. Otherwise, we are confident that most observed older notches are Last Interglacial in age, as such sharp profiles (Fig. 4B and C) would be unlikely to survive dissolution, denudation, and weathering since the middle Pleistocene. However, even preservation of MIS 5e notches is relatively rare.

Minimal surface lowering rates in the Bahamas may be on the order of $1 \mathrm{~m} / 100 \mathrm{ka}$ (Hearty, 1997). As MIS 7 (ca 200-240 ka) sea level probably did not rise above present, the next older opportunity to form a notch higher than present would be MIS 9 or 11. Only under extraordinary circumstances (immediate burial and recent exhumation; extreme aridity) could a 1- to 3-m-deep notch in limestone survive $300-400 \mathrm{ka}$.

Bioerosional notches in their landward position relative to the reef or terrace flats are of fundamental importance to the understanding of MIS 5e sea levels (Neumann and Hearty, 1996). Cutting of high notches in landward cliffs of pre-5e rocks occurred after the bulk of MIS 5e time had transpired. Had notching occurred early in the interglacial, it would likely be destroyed by subsequent shore retreat over several thousand years, or buried by accreting dune sands.

\section{Case studies: defining MIS 5e sea-level history}

\subsection{Overview}

Geological evidence from the Mediterranean, Bermuda, Bahamas, Barbados, Hawaii, and Western Australia (Fig. 1) is compiled here to establish a sea-level history. Deposits and geomorphology recording sea-level changes are sampled from widespread global locations in order to minimize local effects. A sampling of published curves in Fig. 2 reveals the changing position of sea level during the later half MIS 5e. Periods of stability or change, common to numerous sites, are defined here as SLIs. SLIs are numbered 1-6 from oldest to youngest. As the following case studies will demonstrate, SLIs represent coeval sea- level fluctuations, often expressed differently in terms of morphology, composition, or facies at various sites. These proposed SLIs are SLI\#1 - transgression to a position above present; SLI\#2 - period of stability in early part of highstand; SLI\#3 - fall to near or below present position $(0 \mathrm{~m})$; SLI\#4 - rise and second interval possible temporary stability above present; SLI\#5 - rise and peak of sea level at several metres above previous levels \#2 and \#3; and SLI\#6 - fall of sea level below present.

SLI numbers are used throughout the following text, images, and stratigraphic sketches. Together they provide the observational basis, frequency of occurrence, diversity of facies, and spatial dimension of each of the sea-level changes. The cited publications provide additional documentation of the geology and geochronology of each site.

\subsection{The Mediterranean basin}

\subsubsection{Site 1-the Mediterranean: general observations}

Over 50 Last Interglacial sites have been stratigraphically logged and dated with AAR from the Mediterranean Basin. $\alpha-\mathrm{U} / \mathrm{Th}$ ages on the solitary coral, Cladocora caespitosa, have confirmed the MIS 5e correlation at about $15 \%$ of the sites, providing age-calibration for widespread sites lacking corals or radiometric ages. Northern and central Italy, Spain, Mallorca, and Tunisia are generally considered to be areas having a low rate of tectonic movement, based on the current position of MIS 5e deposits. Overviews of the geology and interpretation of sea-level oscillations during MIS 5e in the Mediterranean Basin are presented elsewhere (Hearty, 1986, 1987; Hearty et al., 1986).

\subsubsection{Site 2-Tunisia}

At Hergla South near Sousse in the southern Gulf of Hammamet, Tunisia, Herm et al. (1980) described a stratigraphic section (Fig. 6) rising to about $+8 \mathrm{~m}$ that includes, from the base upward: a marine unit with shells (SLI\#2), a thin eolianite, a weathering surface (SLI\#3), a second marine unit with shells (SLI\#4-5), capped by a second eolianite. This stratigraphy would place the early marine unit at about $+3 \mathrm{~m}$, and the second above $+4 \mathrm{~m}$. Miller et al. (1986) established from A/I ratios on Glycymeris shells that both marine units were statistically identical in age, and were most likely correlated with MIS 5e. This correlation was confirmed with an U/Th age of $126 \pm 7 \mathrm{ka}$ from a coral associated with the formation (Hearty, 1986).

\subsection{Bermuda}

\subsubsection{Site 3-Bermuda general}

The Bermuda platform is considered by many to be the pre-eminent Quaternary type-site for sea level, as it exposes evidence of interglacial highstands well into the middle and early Pleistocene. Set upon a $30 \mathrm{Ma}$ volcanic seamount based in the abyssal plain of the western Atlantic Ocean, 
Hergla South Tunisia

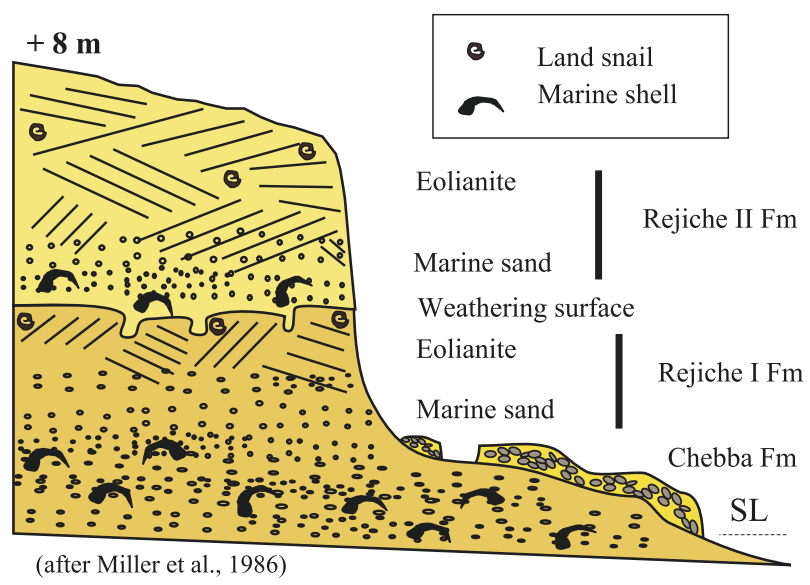

Fig. 6. Geologic field sketch from Hergla South, Tunisia (redrawn after Herm et al., 1980) showing early (SLI\#2) and late (SLI\#4-5) MIS 5e marine deposits (Miller et al., 1986) separated by a well defined weathering horizon (SLI\#3). Amino-acid values (A/I) on Glycymeris violescens are equivalent in lower and upper marine units, and the age of the deposit is confirmed by an age of $126 \pm 5 \mathrm{ka}$ on Cladocora caespitosa, a branching solitary coral.

subsidence is most likely the only tectonic consideration in sea-level studies. A recent revision of the late Quaternary stratigraphy (Hearty, 2002a) was based on two decades of geological field observations of Bermuda, seen from the perspective of other global records. Formerly correlated with MIS 7 (Vacher et al., 1989, 1995; Hearty et al., 1992; Muhs et al., 2002), the $+2.5 \mathrm{~m}$ Belmont shoreline (SLI\#2) is now equated with early MIS 5e. This interpretation is based on AAR ratios from whole-rock, Glycymeris, and Brachiodontes shore and notch deposits, as well as reinterpretation of previous $\mathrm{U} / \mathrm{Th}$ coral ages on coral cobbles. As no in situ Pleistocene coral reefs or growth position corals are exposed in Bermuda, we interpret the range of ages between MIS 9, 7, and 5e (Harmon et al., 1978, 1981, 1983; Muhs et al., 2002) to be the result of facile reworking of coral cobbles and "stems", in the case of Oculina, into progressively younger deposits. The revised stratigraphy of Bermuda falls into accordance with a more general view of middle and late Pleistocene sea-level history, and reinforces its importance as a global sea-level 'tide gauge' (Land et al., 1967).

\subsubsection{Site 4-Grape Bay, Bermuda}

MIS 5e sea levels are best defined along the South Shore in numerous exposures at Grape Bay (Meischner et al., 1995; Hearty, 2002a). The base of the section exposes a firmly indurated subtidal to intertidal facies transition indicating a sea level at $+2.5 \mathrm{~m}$ (SLI\#2). The top of the sedimentary sequence is eroded and locally capped by reddish colluvium, formerly interpreted as a glacial soil. The reddish colour was probably derived from the red middle Pleistocene soils on the adjacent hillsides (Hearty, 2002a). The overlying Devonshire marine unit (SLI\#4) has a conglomerate at its base and is loosely consolidated sand throughout. This difference in degree of induration led Meischner et al. (1995) to conclude that the lower unit was much older. Marine cementation in the mixed phreatic zone during the later highstand was more likely responsible for the greater induration of the older unit. In some locations further east in Grape Bay, subtidal cross beds rise in the younger unit to $+5-6 \mathrm{~m}$ (SLI\#2) which corresponds with the inner edge of a narrow terrace in a sea cliff at Hungry Bay further to the west (Hearty and Kindler, 1995). The succession is capped by the Harrington soil (SLI\#6) and Hungry Bay eolianite (former Pembroke Mb).

\subsubsection{Site 5-Spencer's Point, Bermuda}

The Spencer's Point conglomerate, situated on a narrow rubble bench and small notch near Saucos Hill on the South Shore, was surveyed at $+9.2 \mathrm{~m}$ in 1989 (with H.L. Vacher and H.A. Curran) (Hearty, 2002a). A $\alpha \mathrm{U} / \mathrm{Th}$ age on a coral cobble from Spencer's Point was first reported by Land et al. (1967) at $130 \pm 15 \mathrm{ka}$, but the same sample later gave an age of $97 \pm 9 \mathrm{ka}$ (Harmon et al., 1978). Although now mostly destroyed, the Spencer's Point deposits were first associated with the broad sea-level peak (Land et al., 1967). Here the deposits are equated with SLI\#5 in late MIS 5e.

\subsection{Site 6-Christ Church Parish, Barbados}

Although more uplifted $(\sim 20 \mathrm{~m} / 100 \mathrm{ka}$ on the south coast) than most sites in this review, the reef tracts in western and southern coasts have been extensively studied and dated by a variety of $\mathrm{U} / \mathrm{Th}$ and electron spin resonance (ESR) techniques (history summarized in Schellmann and Radtke, 2004) and thus merit discussion in this study. Mesolella et al. (1969) correlated the Barbados III terrace with MIS 5e, but noted its "bifurcation" in Christ Church Parish.

The lower Maxwell terrace rises to about $+23 \mathrm{~m}$ and has yielded MIS 5e ages averaging $120 \mathrm{ka}$, but including two TIMS U/Th ages of $128.7 \pm 3.0$ and $127.6 \pm 2.5$. The higher Rendezvous Hill terrace crests at ca +37 , and yields a slightly younger average U/Th age of ca $117 \mathrm{ka}$, but also contains some older MIS 5e ages ( $\mathrm{Ku}$ et al., 1990). Schellmann and Radtke (2004) determined average ESR ages for the Maxwell ("T4": $118 \pm 9 \mathrm{ka}(N=8)$ ), and subdivided the Rendezvous Hill into two subterraces ("T5a": $128 \pm 11 \mathrm{ka} \quad(N=14)$ and "T5b": $132 \pm 13$ $(N=15))$ equated with the "Maximal Last Interglacial sea level." Unfortunately, the low resolution of ESR and morphological interpretation of the site does not clarify questions of sea level.

Our whole-rock A/I ratios on the reef sediment matrix at the two type sites support a younger, higher Rendezvous Hill, and an older, lower Maxwell, with mean A/I values of $0.36 \pm 0.02(N=4)$ and $0.48 \pm 0.04(N=4)$, respectively. 
The younger A/I is confidently correlated with several late MIS 5e ages ca $120 \mathrm{ka}$, while the higher value is appropriate for an older MIS 5e deposit, given the effect on epimerization caused by interglacial warmth (as in Hearty, 2002a). On the basis of our observations and data, we propose a correlation of Maxwell and Rendezvous Hill terraces with our SLI\#2 and SLI\#4-5, respectively. The Rendezvous Hill road cutting exposes a nearly monospecific coral thicket of Porites corals, hinting at rapid growth; we suspect in response to rising sea level during SLI\#5.

One-half of the $14 \mathrm{~m}$ difference between terraces can be explained by our sea-level model; another $2 \mathrm{~m}$ by the assumed constant uplift rate, leaving perhaps a paleo-water depth, or co-seismic events to explain the remaining $5 \mathrm{~m}$ difference between the two terraces. In contrast to our findings, Thompson and Goldstein's (2005) 'open-system' recalculation of $\mathrm{U} / \mathrm{Th}$ coral ages from their own work and previous studies in Barbados yield a saw-tooth double MIS 5e sea-level curve (Fig. 2; plate "L"), with twin $+5 \mathrm{~m}$ peaks at 120 and $115 \mathrm{ka}$, separated by an extreme $14 \mathrm{~m}$ regression.

\subsection{Bahamas}

\subsubsection{Site 7-Bahamas general}

The Bahamas Archipelago is a vast array of pristine carbonate islands, platforms, and shallow marine wilderness. On the islands, there are numerous exposures of subtidal, intertidal, and supratidal eolianite facies; a majority probably tied to MIS 5e. Unfortunately, only a few islands have received any detailed scientific attention. Garrett and Gould's (1984) study on New Providence Island stands out as a landmark investigation, and it, too, includes a bipartite MIS 5e. The reader is directed to several overviews of Bahamian geology (Hearty and Kindler, 1993a, b; Curran and White, 1995; Kindler and Hearty, 1996, 1997, Hearty and Kaufman, 2000).

\subsubsection{Site 8-Cockburn Town, San Salvador Island (SSI)}

SSI is among the better-studied islands in the Bahamas by virtue of the facilities supplied by the Bahamian Field Station (Gerace Research Centre). TIMS dating of corals from the Cockburn Town reef suggests growth between 132 and $119 \mathrm{ka}$, with a stable sea level at $+6 \mathrm{~m}$ between 126 and $123 \mathrm{ka}$ (Chen et al., 1991); however, no reef is found at that level. On SSI and other Bahamian islands, the maximum height of in situ corals is $+2.5 \mathrm{~m}$ (SLI\#2), which is interpreted to be the average early MIS 5e sea level in the microtidal Bahamas (Neumann and Hearty, 1996).

Hearty and Kindler (1993b) traced an erosional unconformity (SLI\#3) to below sea level, separating two intervals of reef growth (SLI\#2/4) at Cockburn Town (Fig. 7). A few km inland (east) from Cockburn Town reef, a small rock quarry exposes subtidal/intertidal structures indicating a sea level of $\sim+7 \mathrm{~m}$ (SLI\#5) based on WR A/I (Hearty and Kindler, 1993b). Chen et al. (1991, p. 94) rejected a double MIS 5e at San Salvador, but some of these authors later recognised (White et al., 1998) the same unconformity described earlier (Hearty and Kindler, 1993b).

\subsubsection{Site 9-Hole in the Wall, Abaco Island}

Similar to Cockburn Town, the Hole in the Wall stratigraphy exposes two intervals of reef growth below $+3 \mathrm{~m}$ (Fig. 7A and B), separated by an erosional unconformity on the lower reef and adjacent eolianite substrate. Small sea cliffs and notches at $+2.5 \mathrm{~m}$ form the landward margin of a $45 \mathrm{~m}$ wide terrace at that level. SLIs\#1 through \#4 are represented stratigraphically in the reef, subtidal, and beach facies, and are duplicated upwards geomorphologically by a terrace at $+2.5 \mathrm{~m}$, sea cliffs, notches, sea caves, and planation surfaces between +6 to $+10 \mathrm{~m}$. In a rare example of $\mathrm{U} / \mathrm{Th}$ age concordance with stratigraphy, the slightly altered lower reef generated a marginally reliable MC-ICPMS U/Th age of $127 \pm 3.5 \mathrm{ka}$ (Table 1), while above the unconformity, the upper reef corals produced ages of $120 \pm 2.5 \mathrm{ka}(N=3)$. The excellent stratigraphy and geomorphology, and adequate geochronology from Hole in the Wall make it one of the more instructive MIS 5e localities.

\subsubsection{Site 10-Lyford Cay, New Providence Island}

The surficial geology of NPI was first presented in Garrett and Gould (1984), where they included a detailed sketch of the deep Lyford Cay road cutting. They identified seven units ("i-vii") and these are shown in our more detailed morphostratigraphic section in Hearty and Kindler (1997) (see also Figs. 7E and F). The seven units consist of marine or aeolian deposits, each bounded by either a red paleosol (Unit "ib"), brown to tan protosols (Units "ii" to "vi"), or a dark brown soil across the entire ridge surface. Intertidal marine beds of oolite were identified in Units "ii" and "iii" by Garrett and Gould (1984) and Hearty and Kindler (1997), and oolite was dated at $128-117 \mathrm{ka}$ by Muhs et al. (1990). The intertidal marine beds are separated by a "washed" or eroded unconformity, rising landward into a protosol. Both WR and Cerion land snail amino-acid data firmly link all of the complex succession with MIS 5e (Hearty and Kindler, 1997; Hearty and Kaufman, 2000), except for the lowest unit (Unit "i", MIS 7 or 9?). The subtidal-intertidal interface (as in nearby Clifton Pier, Fig. 3) is not exposed, as it probably lies below road level at ca $+9 \mathrm{~m}$; however, the section clearly shows evidence in intertidal beds rising to over $+15 \mathrm{~m}$ of two energetic marine phases (SLI\#2 and \#5), perhaps reflecting periods of intense storms.

A somewhat higher elevation double MIS 5e section in a road cutting along Collins Avenue in central Nassau town exposes the cast and sand mould of a large arboral structure with its base in a mid MIS 5e protosol (Fig. 7D) sandwiched between early and late MIS 5e eolianites. 

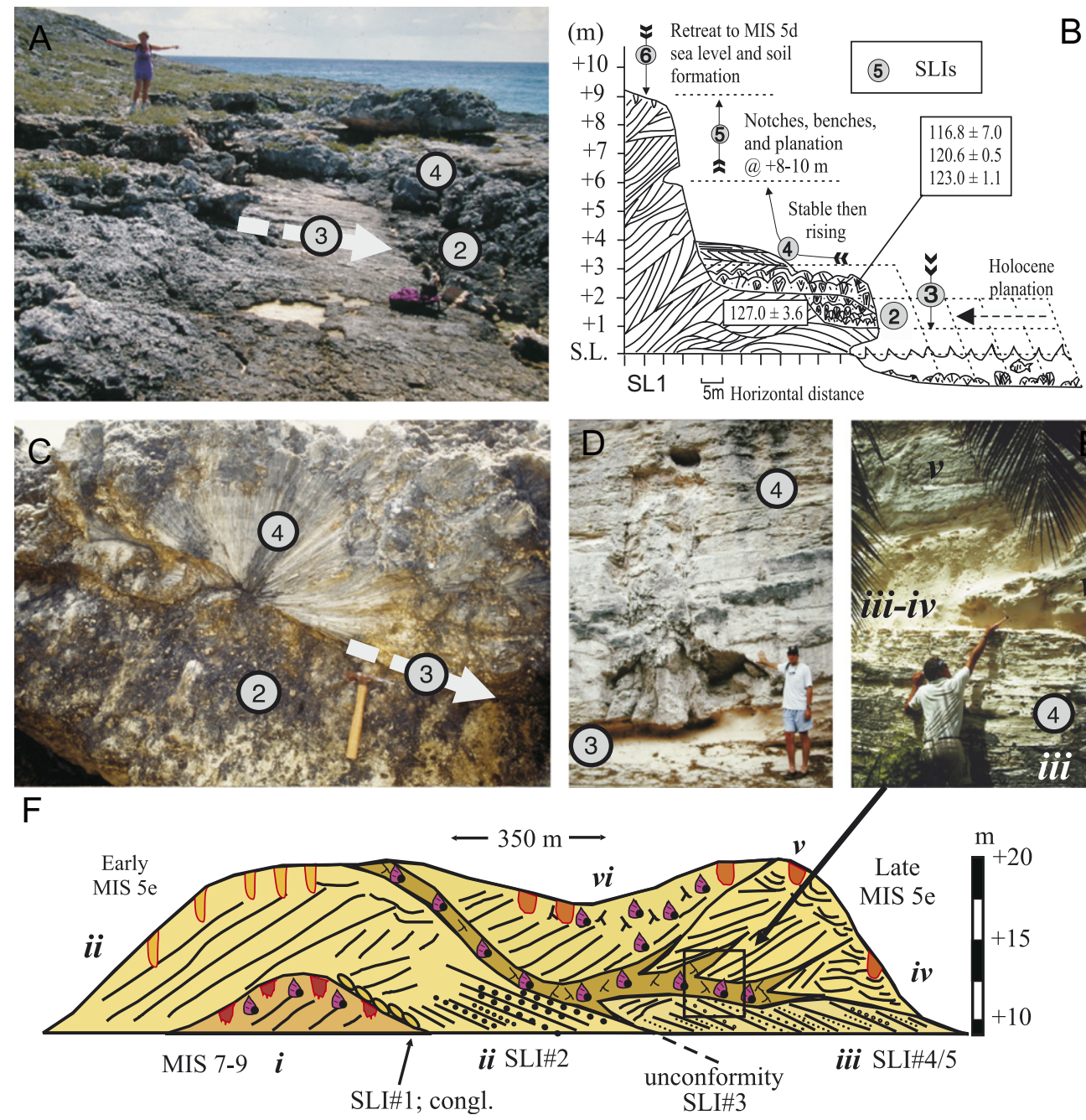

Fig. 7. Geologic evidence of sea-level changes (indicated by SLIs) during MIS 5e in the Bahamas. (A, B) A double MIS 5e reef at Hole in the Wall (southernmost Abaco Island, Bahamas); (C) In situ MIS 5e corals below and above an erosional unconformity (Cockburn Town, San Salvador Island, Bahamas); (D) Tree-like cast and mould in MIS 5e eolianite. The tree structure, buried by late MIS 5e eolianite, is based in mid MIS 5e soil developed on early MIS 5e eolianite (Collins Avenue, Nassau, Bahamas); (E, F) A relatively complete MIS 5e succession showing early and late marine phases (ii) and (iii), and a final succession of three eolianites (iv-vi), possibly linked to rapid sea-level shifts and intense storminess late in MIS 5e. Stratigraphic terminology (i-vi) from Garrett and Gould (1984) and Hearty and Kindler (1997).

\subsection{Oahu, Hawaii}

The excellent double-MIS 5e sea-level exposures on Oahu parallel those from more stable locations like Bermuda and the Bahamas, but are consistently higher in elevation by $2-3 \mathrm{~m}$, conforming with a well-established uplift rate of approximately $2 \mathrm{~m} / 100 \mathrm{ka}$ (Muhs and Szabo, 1994; Hearty et al., 2000) since MIS 5e.

\subsubsection{Site 11-East Coast (Mokapu Point, Kaneohe Marine Base, and Costa Dairy)}

A stratigraphic section at Mokapu Point (Fig. 8) is floored on an erosional bench cut into middle Pleistocene crater-lake sediments at $+5 \mathrm{~m}$ (Wentworth and Hoffmeister, 1939; Hearty et al., 2000, 2005). Erosional troughs in the lake sediments are filled with a transgressive conglomerate (SLI\#1), while Porites corals rest in place on the terrace bench at $+5 \mathrm{~m}$ (SLI\#2).
There is no conspicuous evidence of subaerial exposure (SLI\#3) at Mokapu, but on the north coast near Kaena Point, an erosional surface is conspicuous within the MIS 5e sequence (Sherman et al., 1993). At Mokapu, the reef environment was flooded by several metres of basalt conglomerate that coarsens upward. This conglomerate presumably formed as sea level transgressed upon the weathered volcanic landscape (SLI\#4/5), causing the erosion, mobilization, and transport of wellrounded basalt clasts, possibly shaped either during earlier marine stages, or as corestones within the volcanic soils.

Seated upon these boulder shoals are thickets of Pocillopora meandrina and other fast-growing species, rising to over $+9 \mathrm{~m}$. The coral thickets are locally buried with $1-3 \mathrm{~m}$ of subtidal and intertidal sands up to about $+12 \mathrm{~m}$. These higher levels (SLI\#5) appear to equate broadly with horizontal notches at +6.7 and +8.6 , and 


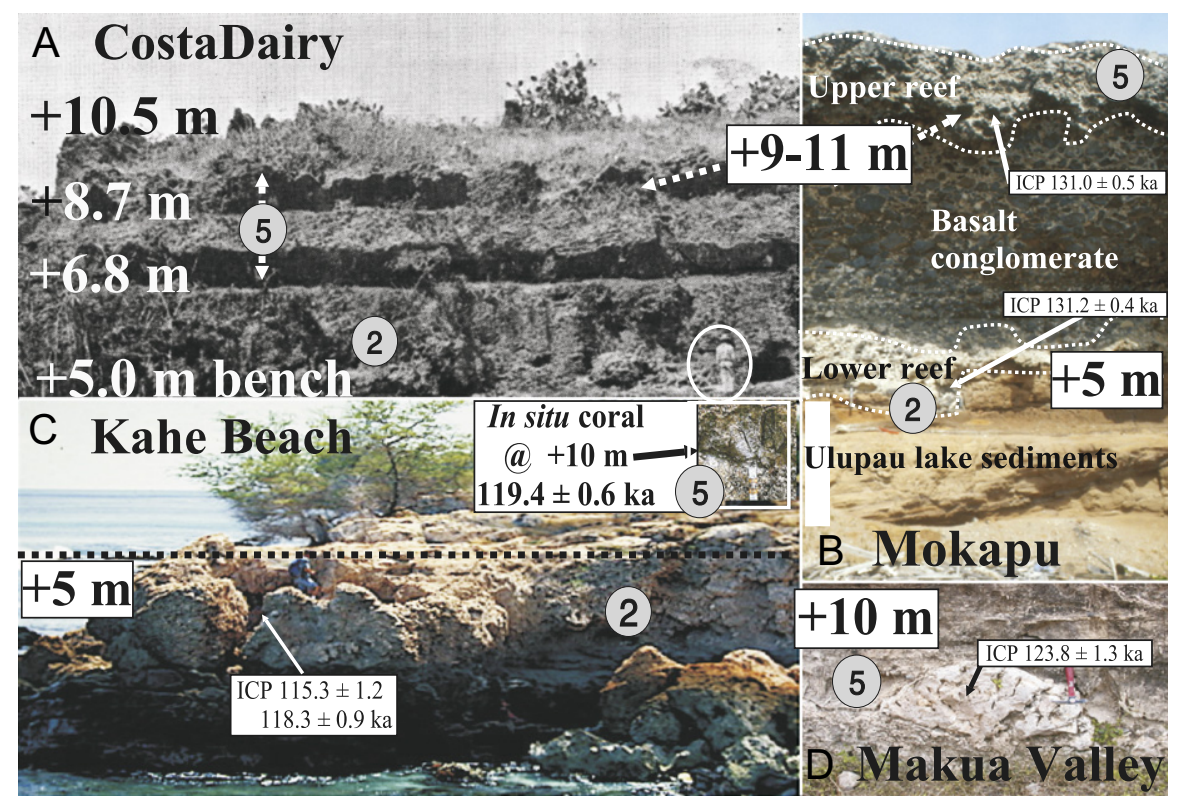

Fig. 8. Geologic evidence of sea-level changes (indicated by SLIs) during MIS 5e on Oahu, Hawaiian Islands. (A) Stearns' (1978) photo from 1935 of two notches at +6.8 and $+8.7 \mathrm{~m}$ (above a $+5 \mathrm{~m}$ bench), and planation surface at $+10.5 \mathrm{~m}$ cut into a middle Pleistocene eolianite at the former location of Costa Dairy. The site has long since been destroyed, but the photo preserves evidence of SLI\#2 at $+5 \mathrm{~m}$, and several shifting positions during SLI\#5 $(+6.8,+8.7$, and $+10.5 \mathrm{~m})$; (B) Mokapu section showing lower $(+5 \mathrm{~m}$ : SLI\#2) and upper reefs $(+9-10.5 \mathrm{~m}$ : SLI\#5). (C) Fringing reef terrace at $+5 \mathrm{~m}$ (SLI\#2) at Kahe Beach Park, with inset of in situ coral at $+11 \mathrm{~m}$ (SLI\#5) across Farrington Highway yielding a marginally unreliable coral age of $119 \pm 0.6 \mathrm{ka}$; (D) Growth position coral head at $+10 \mathrm{~m}$ in a road cut at Makua Valley near Kaena Point yielding a reliable age of $123.8 \pm 1.3 \mathrm{ka}$.

a planation surface at $+10.5 \mathrm{~m}$ (Fig. $8 \mathrm{~A}$ ) described by Stearns (1978, p. 35, Fig. 14) in a middle Pleistocene cliff (since quarried away) at the former Costa Dairy near Kailua. Similarly spaced sets of notches have been described near Sorrento Italy (Riccio et al., 2001).

A considerable number of $\alpha$, TIMS, and MC-ICPMS U/Th ages (Ku et al., 1974; Muhs and Szabo, 1994; Szabo et al., 1994; Muhs et al., 2002; Muhs et al., this study) from the deposits confirm a MIS 5e age, but fail to corroborate the exquisite lithostratigraphic succession of this site, as most ages do not pass reliability standards. Even without accurate dating, Mokapu is critically important for this review because it exposes two stacked, in situ coral reefs, separated by a terrigenous basalt conglomerate, all of which unambiguously document the $>5 \mathrm{~m}$ rise of sea level between SLI\#2 and SLI\#5.

\subsubsection{Site 12-West Coast (Makua Valley and Kahe Beach)}

At Kahe Beach State Park (Muhs and Szabo, 1994), located $10.5 \mathrm{~km}$ south of Waianae, two in situ reef levels are similarly exposed: a lower broad terrace at $+5 \mathrm{~m}$ (Fig. $8 \mathrm{C})$, and a small outcrop across Farrington Highway near the power station with in situ corals at +9 to $+10 \mathrm{~m}$, capped by a marine conglomerate at ca $+12 \mathrm{~m}$ (Hearty et al., 2000). Our MC-ICPMS-U/Th ages of $131.2 \pm 0.4$, $118.3 \pm 0.9$, and $115.4 \pm 1.2 \mathrm{ka}$ were determined from the lower reef, and $119.4 \pm 0.6 \mathrm{ka}$ from an in situ coral head in the higher outcrop. Although mostly deemed unreliable (Table 1), the ages generally support a higher, younger MIS 5e sea level, in agreement with Muhs et al. (2002). A double
MIS 5e was similarly interpreted from an excavated irrigation drain near Barber's Point on the SW shore of Oahu (Sherman et al., 1993), with the exception of lower late MIS 5e peak at $+5 \mathrm{~m}$.

Near Makua Valley, $7 \mathrm{~km}$ SE of Kaena Point, corals are exposed in a 400-m-wide fossil reef terrace (Fig. 8D) at $+5 \mathrm{~m}$ (SLI\#2). On the landward edge in a road cut on Farrington Highway, Porites corals in growth position and subtidal marine deposits are exposed between +9 and $+11 \mathrm{~m}$ (SLI\#5) (Fig. 8), yielding one reliable MC-ICPMS$\mathrm{U} / \mathrm{Th}$ age of $123 \pm 1.3 \mathrm{ka}$ (Table 1$)$.

\subsection{Western Australia}

\subsubsection{Site 13-Perth area (southwest Western Australia)}

MIS 5e marine deposits around Perth and Rottnest Island ( $18 \mathrm{~km}$ offshore) demonstrate the impressive lateral shifts in the coastal depocentre as a result of oscillations of sea level during the highstand (Hearty, 2003). An exposed reef at Fairbridge Bluff on Rottnest rises to no more than $+2 \mathrm{~m}$, while $25 \mathrm{~km}$ eastward at Minim Cove in the Swan River estuary, MIS 5e estuarine deposits with articulated molluscs accumulated up to $+7 \mathrm{~m}$ (Fairbridge, 1953). The age of Minim Cove is confirmed by A/I correlation with the MIS 5e coral reef at Fairbridge Bluff (Murray-Wallace and Kimber, 1989), and verifies the ESR results of Hewgill et al. (1983). We argue that these deposits at Rottnest and Minim Cove represent distinct early and late MIS 5e sealevel oscillations (SLI\#2 and \#5), and emphasize the importance of searching a broad topographic range for such deposits. 


\subsubsection{Site 14-Cape Cuvier}

At coastal exposures south of Cape Cuvier, the eroded seaward margin of the 50-m-wide fringing reef platform was surveyed at $+3 \mathrm{~m}$, thinning and feathering out at $+5 \mathrm{~m}$ on its landward margin. Growth position corals, commonly with flat, planed-off upper surfaces, generally lie below $+4 \mathrm{~m}$ on the platform (SLI\#2). At Cape Cuvier proper, a 30-cm-thick algal rim with small in situ corals is situated landward of the lower reef flat at $+9-10.5 \mathrm{~m}$ (SLI\#5) (Fig. 9A and B). Subtidal and beach deposits are exposed at $+10 \mathrm{~m}$ (SLI\#5) several hundred metres to the south of the Cape (Fig. 9C). Both lower and upper levels average about $1 \mathrm{~m}$ higher than those in Bermuda and Bahamas, but fall within measuring error. Denman and van de Graaff (1976) and Veeh et al. (1979) initially described and dated these deposits, and tentatively speculated that the lower and upper marine units might be the result of two different sea level events, rather than extreme tectonic tilting; the latter hypothesis strongly favoured by others (Playford, 1988; Stirling et al., 1998).

Early $\alpha-\mathrm{U} / \mathrm{Th}$ analyses (Veeh et al., 1979) returned ages of $123 \pm 11 \mathrm{ka}(N=2)$ for the lower, and $134 \pm 8,120 \pm 10$ and $140 \pm 12 \mathrm{ka}$ for the upper rim. TIMS analyses from corals quoted from " $+6.57 \mathrm{~m}$ and $+8.61 \mathrm{~m}$ " levels
(Stirling et al., 1998, p. 752, Table 1) returned ages of $128 \pm 0.7$ and $126 \pm 0.5 \mathrm{ka}$, respectively, from a location $14 \mathrm{~km}$ north of Cape Cuvier near the wreck of the Korean Star. They consider these ages to be unreliable due to elevated initial $\delta^{234} U$ values. We similarly described a locality near the Korean Star where a MIS 5e beach rests on a $+10 \mathrm{~m}$ bench. This beach was uniquely preserved by the collapse of a massive boulder (Fig. 9D). The age was confirmed by calibrated WR and marine shell AAR assays, while an abraded coral fragment from the beach returned a spurious age of $191.7 \pm 3.2 \mathrm{ka}$ (Table 1). In the same area, near the wreck of the Korean Star, a $+4 \mathrm{~m}$ terrace and $+10 \mathrm{~m}$ rim were recorded by Hollin in the same general area in 1985.

Stirling et al. (1998, p. 749) discounted their finding of “... a Last Interglacial Lower Terrace (our emphasis; was there an upper terrace?) at 7-9 $\mathrm{m}$ above the present day intertidal platform...", attributing the elevation of the corals to "localized tectonics" and uplift at a rate of $0.06 \mathrm{~m} / \mathrm{ka}$. At our study area south of Cape Cuvier, a "lower terrace" occurs at $+3-4 \mathrm{~m}$, and an "upper terrace" beach and coralgal rim at ca $+10 \mathrm{~m}$, and at precisely the same elevations as at the Korean Star, supporting our view that eustatic sea-level changes, and not local tectonics are the most reasonable explanation for these features.
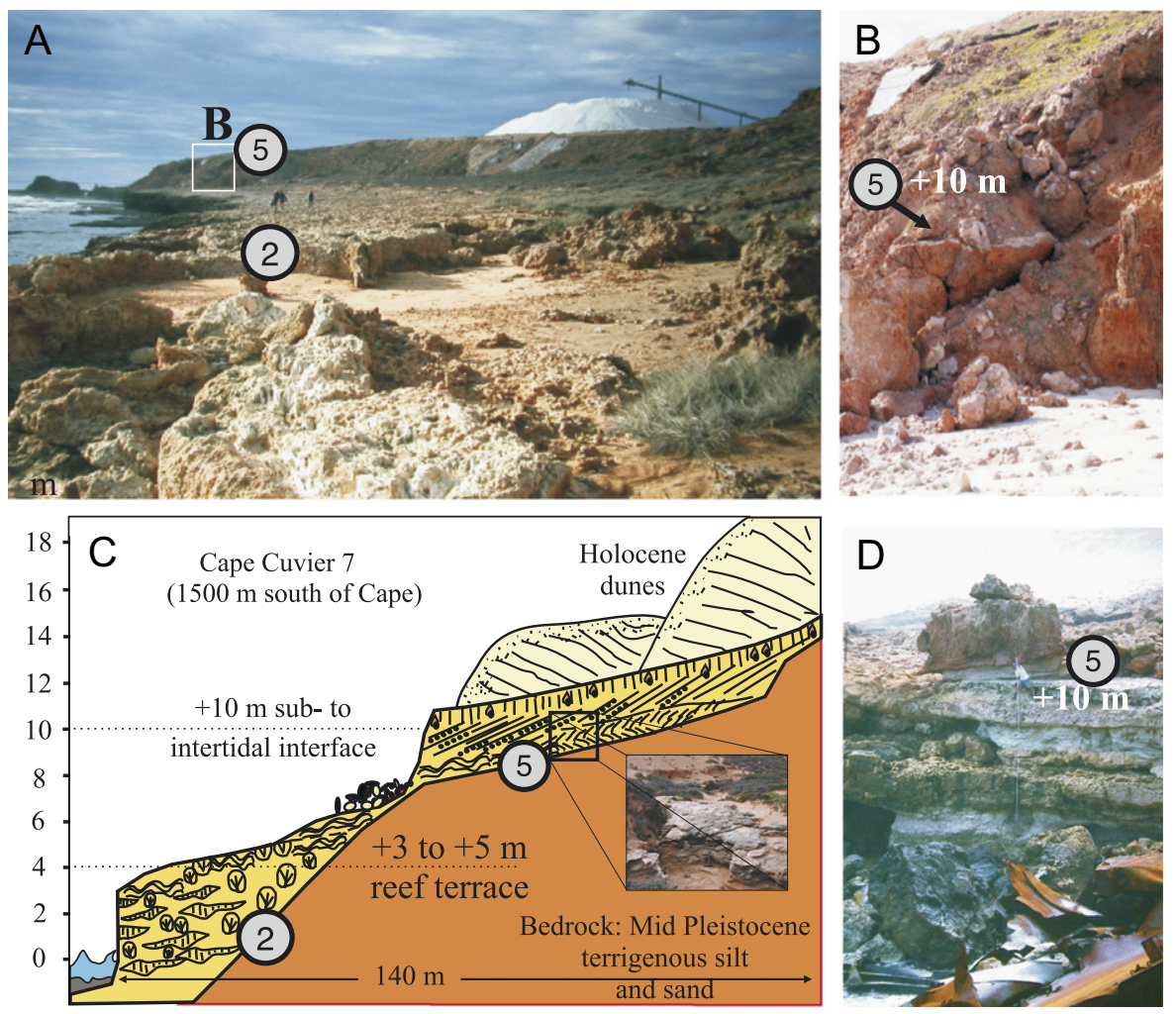

Fig. 9. Geologic evidence of sea-level changes (indicated by SLIs) during MIS 5e from Western Australia. (A) A northward view of the 50-m-wide, +3 to $+5 \mathrm{~m}$ reef terrace (SLI\#2) at Cape Cuvier (upper left of photo); (B) View of upper coralgal rim at $+10 \mathrm{~m}$ (arrow: SLI\#5), first described by Denman and van de Graaff (1976). No MC-ICPMS ages from Cape Cuvier are considered reliable, but the morphostratigraphy is strikingly similar to that in Hawaii when a minor tectonic correction is applied. (C) A surveyed $140 \mathrm{~m}$ cross-section and schematic drawing $1500 \mathrm{~m}$ south of Cape Cuvier showing the $+4 \pm 1 \mathrm{~m}$ reef terrace, and a landward facies transition from subtidal to intertidal at $+10 \mathrm{~m}$ (inset) (O'Leary, 2007). (D) A MIS 5e beach, surveyed at $+10 \mathrm{~m}$, is preserved beneath a massive boulder located $14 \mathrm{~km}$ north of Cape Cuvier at the wreck of the Korean Star (foreground). 
Despite our intensive research effort around Cape Cuvier, little clarification is provided by MC-ICPMS ages from five samples from the upper and seven samples from the lower terraces (Table 1), which produced a spread of ages between ca 137 and $118 \mathrm{ka}$ (O'Leary, 2007). The dates confirm a MIS 5e age, yet only the excellent morphostratigraphy allows us to establish confidently that the broad $+3-4 \mathrm{~m}$ terrace and upper $+10 \mathrm{~m}$ coralgal rim are the result of early sea-level stability (SLI\#2), and a late brief rise of sea level at the end of MIS 5e (SLI\#5), in near perfect agreement with other global locations.

\subsubsection{Site 15-Cape Range, (northwest Western Australia)}

Kendrick et al. (1991) recognised "dual" coastal ridges and marine deposits associated with MIS 5e in the Cape Range area. The older more landward ridge at Pilgramunna Creek produced a single coral age of $130 \pm 6 \mathrm{ka}$ (our SLI\#2), while the younger ridge gave an age of $118 \pm 5 \mathrm{ka}$ (SLI\#4-5). We corroborate the geological observations of Kendrick et al. (1991) and add geomorphic evidence that the MIS 5e shoreline eroded a cliff and notches in the Jurabi terrace (MIS 11?) up to +8 to $+10 \mathrm{~m}$. The evidence consists of notches in the older reef, and a rubble zone above a planation surface/algal pavement much like that of the coralgal rim at Cape Cuvier and nearby rocky shorelines. Two well-preserved, unabraded Acropora sp. coral fragments from high in the sedimentary sequence at the onlap with the Jurabi at $+8 \mathrm{~m}$ terrace yield two reliable MC-ICPMS-U/Th ages of $123.8 \pm 0.6$ and $124.5 \pm 0.7 \mathrm{ka}$, indicating that the time of transport must be younger than the living corals $124 \pm 1 \mathrm{ka}$ ago (i.e., SLI\#5).

\section{A composite sea-level model for MIS 5e}

Fig. 10 is a sea-level model constructed using the sum of evidence from 15 of the most complete MIS 5e localities. The coherence of sea-level indicators established by correlation of SLIs across regions and coastal facies justifies the construction of this global composite. The curve reflects relative changes in sea level and incorporates an assumed uncertainty of $\pm 1 \mathrm{~m}$ (effects of measuring error, local and regional effects of tides, hydroisostasy, and minor tectonic effects) at all points in the curve. The events, intervals, and estimated ages are defined as follows:

SLI\#1-This level equates with deglacial rise of sea level during Termination II above present around $130 \pm 2 \mathrm{ka}$. SLI\#1 is commonly expressed as transgressive basal conglomerate, often with reworked limestone and coral cobbles, deposited on a calcrete-indurated, red-stained and scoured older Pleistocene bedrock base.

SLI\#2-Sea level stabilized early in MIS 5e at $+2.5 \pm 1 \mathrm{~m}$. This important interval lasted for $5-7 \mathrm{ka}$ between ca 132 and $125 \mathrm{ka}$. Broad sedimentary or fringing reef terraces, and significant enlargement of the coastal ridge are the primary evidence of this event.

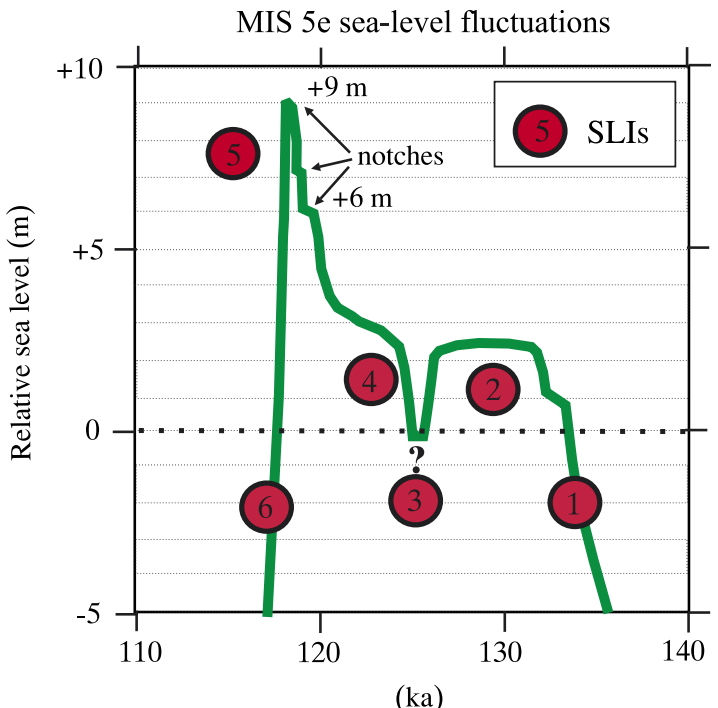

Fig. 10. A reconstruction of sea-level intervals ("SLI\#1-\#6") during the peak Last Interglaciation, MIS 5e from interpreted from geological observations. The consistency of the relative elevation and succession of these intervals among sites, regions, and ocean basins justify the construction of this composite. An uncertainty of $\pm 1 \mathrm{~m}$ applies to the entire curve and incorporates various inaccuracies of measurement, and the effects of tides, isostasy, and local tectonics.

We consider SLI\#2 to be the most stable period during MIS 5e.

SLI\#3-A short regression followed SLI\#2, lasting only perhaps $1 \mathrm{ka}$ around $125-124 \mathrm{ka}$. It is not certain how far sea level fell below present. This regression imprinted a "double-5e" image by stratigraphically separating (by unconformity or soil formation) marine and dune deposits associated with SLI\#2 and SLI\#4-5 (e.g., Figs. 6-9).

SLI\#4-A second rise of sea level above $+3 \mathrm{~m}$ lasted for a relatively short period from 1 to $3 \mathrm{ka}$ between 124 and $121 \mathrm{ka}$. This is the most poorly defined interval and may be nothing more than a transitional pause between the rises after SLI\#3 and before SLI\#5. Stratigraphic evidence consists of a second period of reef growth above the unconformity formed on the earlier reef as at Cockburn Town, Bahamas (Fig. 7C), or stacked shoreline deposits such as those at Hergla, Tunisia, Lyford Cay, Bahamas, or Mokapu, Oahu.

SLI\#5-The end of MIS 5e is characterized by multiple sharp rises of sea level around 121-119 ka. This interval was characterised by upward shifts and halts of sea level between +6 and $+9 \mathrm{~m}$. One to three bioerosional notches have been observed, along with rubble benches, algal rims, and minimal coral growth at these elevations. SLI\#6-Sea level appears to have retreated rapidly from the SLI\#5 peak elevations between 120 and $118 \mathrm{ka}$, marking the onset of MIS 5d. Rapid fall is supported by the preservation of delicate coral heads and morphological features formed earlier in the period (Neumann and Hearty, 1996). A slow retreat of the sea would have eroded and destroyed these features. 


\section{Discussion}

This reconstruction of MIS 5e serves as a model to be considered at other global locations. We focus on discrete relative sea-level movements that are geologically defined from a variety of sites and facies whose consistency of relative trends, shifts, and global distribution preclude, overwhelm, or obscure the potential local effects of tectonism, glacio-hydroisostasy, as well as diverse styles of erosion and sedimentation. MIS 5e sea-level history and its imprint are complex, revealing long periods of stability, and abrupt upward and downward movements.

\subsection{Sea-level benchmarks during MIS 5e}

A MIS 5e " $+6 \mathrm{~m}$ sea-level datum" continues to be used as a benchmark for oxygen isotope and tectonic uplift calculations. The $+6 \mathrm{~m}$ figure is probably associated with early work in northern Bahamas (Grand Bahama and Abaco; Neumann and Moore, 1975), which referred to a prominent notch at $+5.9 \mathrm{~m}$, and numerous $\alpha-\mathrm{U} / \mathrm{Th}$ ages averaging ca $125 \mathrm{ka}$ from growth position corals near sea level. It was perhaps assumed by many that the high notch and the lower coral level were contemporaneous, and that $+6 \mathrm{~m}$ represented the net change in ice volume (compared to present) for the entire interglacial. However, the evidence presented here shows that the $+6 \mathrm{~m}$ and higher levels were only briefly visited (over hundreds of years) by sea at the end of the interglacial (Neumann and Hearty, 1996), in contrast to the sustained lower sea level at $+2.5 \mathrm{~m}$ in the early half of MIS 5e.

Throughout the Bahamas, we observe that coral reefs grew only to $+2.5 \mathrm{~m}$. SLI\#2 is expressed geologically at a maximum of $+2.5 \mathrm{~m}$ by the life-limiting effects on corals of subaerial exposure. However, despite the absence of any published reports of in situ corals or reefs higher than $+2.5 \mathrm{~m}$ anywhere in the Bahamas, and citing no other evidence, Chen et al. (1991), White et al. (1998) and others maintain that sea level was in a stable position around $+6 \mathrm{~m}$ for several thousand years during the latter half of the highstand. If sea level was over $4 \mathrm{~m}$ higher for $5 \mathrm{ka}$, as they propose, there is no geological or biological explanation why reefs would not grow and fill the available space to that level not only in the Bahamas, but also across the circum-tropical coastlines of the world. Extensive reef growth, terrace formation, and stratigraphic evidence demonstrate that sea level during SLI\#2 was positioned near $+2.5 \mathrm{~m}$ for the entire early half of MIS 5e (ca $132-125 \mathrm{ka}$ ). Subsequent positions of MIS 5e sea level were too brief to result in extensive reef growth or terrace formation.

\subsubsection{Bioerosional notches and the preservation of late MIS 5e sea-level imprints}

In contrast to early MIS 5e, the formation and preservation of corals representing the shifting sea levels of late in MIS 5e are extremely limited. Insufficient time between submergence and emergence, and perhaps unfavourable ecological conditions appear to have limited coral growth during SLI\#5, manifesting the 'catch up' or 'give up' scenarios of Neumann and MacIntyre (1985). As a result, much of the Last Interglacial sea-level history is recorded in notches and rubble benches; their preservation implies formation late in the period. If notches formed in older rocks at $+6 \mathrm{~m}$ early in MIS 5e, and were followed by a subsequent fall and stable position of sea level for several thousand years at $+2.5 \mathrm{~m}$, it is most likely that the rock faces bearing the notches would be destroyed by the attack of the shore, planation of the shore-platform, and intense rock weathering at the shoreline. Our data indicate that the lower stand at $+2.5 \mathrm{~m}$ lasted for several thousand years. It was followed by a rise to, and brief, erratic shifts at and above $+6 \mathrm{~m}$, forming sharp notches (Fig. 4). Regression thereafter left the notches high and dry and subject to a greatly reduced intensity of weathering. Confirmation of the early to late MIS 5e succession from lower to higher sea levels is also preserved in stacked reef sequences in the Bahamas and Oahu.

\subsection{Other sea-level curves}

Some important studies from around the world support our sea-level model. Chappell and Veeh (1978) and Aharon et al. (1980) deciphered complex sea-level histories from a diversity of biologic, stratigraphic, geomorphic, and tectonic data from the Atauro and Timor Islands, and the Huon Peninsula, Papua New Guinea (Fig. 11) that compare well with our Fig. 10. However, this complexity is not shared by many other studies that depend exclusively on U/Th dating of coral reef terraces. Such reef-derived curves are commonly featureless, round

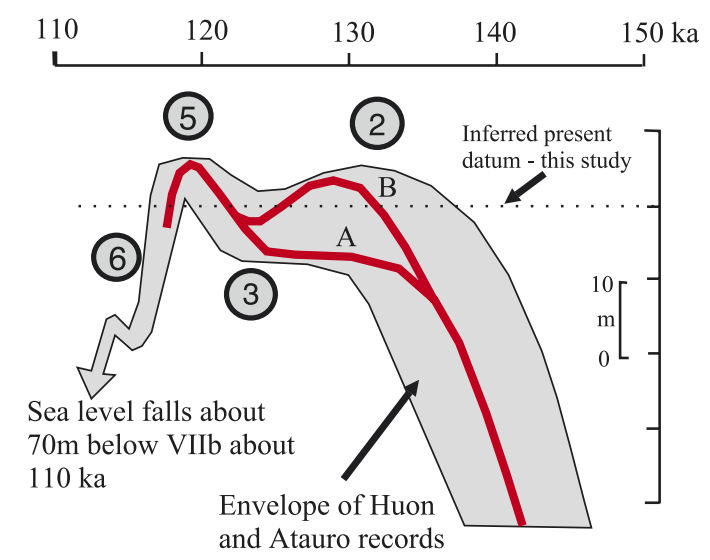

Fig. 11. Sea-level envelope (gray) and scaled sea-level curves (A and B explained in Chappell and Veeh, 1978) distilled from the geology of the tectonically uplifted coastlines of the Huon Peninsula, Papua New Guinea, and Atauro, Indonesia. This curve shows general agreement with the findings from non- and low uplift coastlines presented in this study. Estimated present sea level and a depth/height scale have been added to the original illustration. 
or flat-topped (Chen et al., 1991; Stirling et al., 1998; McCulloch and Esat, 2000; Gallup et al., 2002; Cutler et al., 2003). We interpret these incomplete curves to be the product of restricted sampling of only the reef flat or terraces, which are the most conspicuous, extensive, and best-preserved relic of our SLI\#2, yet not representative of the entire story. The response of reefs to sea-level change is slow, compared to sediment flux or notch-forming processes. A downward shift of sea level would leave the reef flat exposed and subject to erosion and diagenesis. A similar multi-meter upward shift may cause corals to "give up" leaving little imprint on the reef of a significant event. Further, if the sea-level excursion were brief, as we suggest for SLI\#5 to \#6, the reef may not preserve any trace of this change.

\subsubsection{U/Th ages and the subdivision of MIS 5e}

This study provides a means to assess the integrity of $\mathrm{U} / \mathrm{Th}$ dating against the fundamental stratigraphic test of superposition. We find that correspondence of coral ages with stratigraphic order varies regionally and within the geological context of the site (type of bedrock, groundwater, proximity to continental dust, rivers, etc). A general correlation of $\mathrm{U} / \mathrm{Th}$ age and stratigraphy occurs at the Bahamian sites of Cockburn Town reef (Chen et al., 1991; White et al., 1998) and Hole in the Wall, Abaco (this study), which may reflect general aridity and the more pristine carbonate environment there. In contrast, on Oahu, U/Th ages on corals regardless of technique (Ku et al., 1974; Muhs and Szabo, 1994; Szabo et al. 1994, Muhs et al., 2002; this study) produce ages that are generally too old $(133 \mathrm{ka})$ or too young $(<118 \mathrm{ka})$ and lack a significant number of "core" MIS 5e ages.

Attempts to subdivide the Last Interglacial highstand exclusively on the basis of $\mathrm{U} / \mathrm{Th}$ age have been largely inconclusive ( $\mathrm{Ku}$ et al., 1974, 1990; Muhs et al., 2002). Recent order-of magnitude increases in measuring precision of radioisotopes may give the false impression of a corresponding increase in accuracy-less than perfect corals yield less than perfect ages, regardless of technique or transformation. According to Thompson and Goldstein's (2005) 'open-system' model, the transformation of many less than perfect $\mathrm{U} / \mathrm{Th}$ ages from Barbados, renders them sufficiently accurate to be used to independently construct a sea-level curve. The resulting 'curve' (Fig. 12A) is unlike any geologically derived MIS 5e sea-level record, and it is improbable that all these curves (Fig. 2) are equally incorrect. Furthermore, if sea level were to follow this saw-tooth pathway, there would have been insufficient time at the peak sea-level positions to build the extensive reefs and morphological terraces we commonly observe associated with MIS 5e. We suspect that the convergence of "corrected" ages, used in their defence of accuracy, may be more a systematic diagenetic shift than a temporal correction.
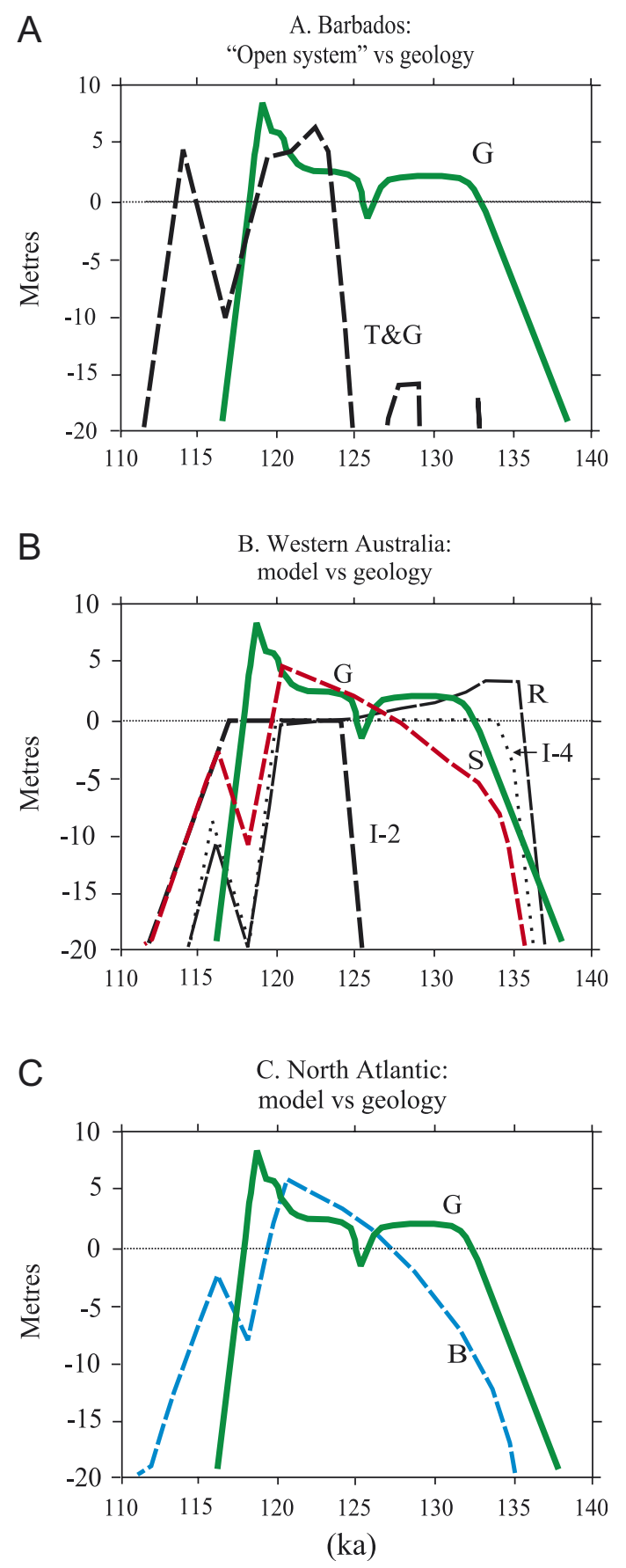

Fig. 12. (A) The age corrected sea-level curve of Thompson and Goldstein ('T\&G') (2005) is also provided for comparison with our global MIS 5e curve. (B) Comparison of predicted glacio- and hydroisostatic sea-level effects on during MIS 5e from far-field Western Australia ('R' = Rottnest Island; '1-4' and '1-2' (Shackleton, 1987); 'S' = Stirling et al., 1995, 1998), and $(\mathrm{C})$ with intermediate-field sites in the Bahamas ('B') and North Atlantic (Lambeck and Nakada, 1992) with geologically ('G') derived sealevel intervals in this study.

\subsubsection{The deep-sea oxygen isotope record and MIS 5e sea- level changes}

One frequent challenge to a high amplitude and frequency MIS 5e sea-level record is that such a record is not observed in the deep-sea oxygen isotope $\left(\delta^{18} \mathrm{O}\right)$ record. 
Given the unquantifiable effects of salinity, temperature, vital effects, carbonate diagenesis, and analytical variation, exacerbated by averaging several tens of organisms, themselves subject to decimetres of bioturbation within the sediments from each core level, a blurred and muted $\delta^{18} \mathrm{O}$ record would be expected. The short-term ice/ocean volume shifts indicated by the sea-level record would almost certainly go undetected. However, some highresolution $\delta^{18} \mathrm{O}$ records show detail within MIS 5e (e.g., Linsley, 1996), offering hope that future advances in precision and measuring capabilities (e.g., single foraminifera analysis) may eventually corroborate the coastal geological evidence presented here.

\subsubsection{Glacio-hydro-isostatic effects and MIS 5e}

There are few similarities between our field-derived sealevel records from sites at various latitudes $\left(40^{\circ}\right.$ to $20^{\circ} \mathrm{N}$ and $\mathrm{S}$ Latitude) and those generated from isotopically derived sea-level curves (Shackleton, 1987), integrated with derived models of sea level for MIS 5e. The effects of glacio-hydroisostasy at near- to intermediate-field sites in Bermuda and the Bahamas, and far-field sites in Western Australia, are predicted to yield distinctly different sealevel histories (e.g., Lambeck and Nakada (1992); Fig. 12B and C). This model predicts that MIS 5e sea level in Western Australia would rise early to ca $+3 \mathrm{~m}$ then fall during the later half, while sea level at the North Atlantic sites would rise only late in the interglacial. With only minor adjustments in elevation, we have established that these sites yield nearly identical records. Residual glaciohydroisostatic effects are apparently sufficiently small that no discernable geological imprint is left on the rock record of MIS 5e sea level.

\subsection{Sources, sequences, and causes of climate and sea-level changes during MIS 5e}

With the exception of a $+2.5 \mathrm{~m}$ higher sea level, the first $6 \mathrm{ka}$ of MIS 5e exhibits similar climatic and eustatic stability to that of the previous 6-7 ka of our present interglacial. Likewise, deep-sea and pollen records suggest similar stability during the first half of the interglacial. In this respect, the Last Interglacial provides a reasonable comparison with the Holocene (Kukla et al., 1997), despite opposing views on this issue (Dansgaard et al., 1993). An important consideration in this comparison is that after a prolonged period of stability during SLI\#2, the ice-oceanographic-atmospheric system apparently began to unravel midway through MIS 5e. That sea level fell several metres $(+2.5 \mathrm{~m}$ to below present $(\mathrm{SLI} \# 3))$ around $125 \mathrm{ka}$ (White et al., 1998) implies an incipient build-up of polar ice, coupled with climate cooling over far less than a thousand years. This ice build-up and dramatic interglacial cooling quickly reversed itself, much in the same manner of the Younger Dryas, with which it has been compared (Tu et al., 2001). At Grand Pile, northeast France, a change late in the interglacial occurred over 20 years and suggested a $15^{\circ}$ latitudinal shift in vegetation communities (equivalent to northern Scandinavia) (Woillard, 1979). There were similar changes in the North Atlantic (Seidenkrantz and Knudsen, 1994). The end of the Eemian around $118 \mathrm{ka}$ was heralded in northern Germany (Sirocko et al., 2005, p. 833) by a 486-yr interval of "dust storms, aridity, bushfire and a decline of thermophilous trees ...", attributed to a "sudden southern shift of the North Atlantic drift", coincident with ice build-up. Studies in the Bahamas also reveal evidence of intense storms at the close of MIS 5e resulting in the deposition of massive boulders and the formation of chevron ridges in far inland positions (e.g., Neumann and Hearty, 1996; Hearty, 1997; Hearty et al., 1998).

The early, higher-than-present stable sea level at +2 to $+3 \mathrm{~m}$ (SLI\#2) for several thousand years appears to have been derived from partial melting of GIS during warmer climate conditions (Overpeck et al., 2006). Yet after this prolonged period of stability, the ice/oceanographic system was thrown into chaos in mid to late MIS 5e. Lacking any other obvious factors, prolonged or slightly increased climate warmth may have been the triggering mechanism. After a slight regression (SLI\#3), a rise and pause during SLI\#4 was followed by a series of sharp sea level rises during SLI\#5. Incremental rises corresponding with notches at about $+6,+7.5($ ?), and $+9 \mathrm{~m}(+6.7,+8.6$, and $+10.5 \mathrm{~m}$ in $\mathrm{Oahu})$. Such upward shifts are reminiscent of late to post-glacial melt water pulses (Edwards et al., 1993; Blanchon and Shaw, 1995), which were attributed to the release of massive meltwater lakes trapped in the disintegrating Laurentide ice sheet. But presumably during MIS 5e the Laurentide ice sheet was greatly reduced or non-existent, so we must look to the West Antarctica ice sheet (WAIS) (Hollin, 1962, p.185; Mercer, 1978; Oppenheimer, 1998) as a possible source of these changes. Rising seas and/or warming oceanographic circulation around WAIS would destroy buttressing ice shelves (Mercer, 1978), triggering the decoupling and collapse of the marine-based ice sheet. If correlated with the high notches, the break up and collapse of the WAIS may have occurred over decades or hundreds of years through a series of ice dam breakouts or ice surging events. The increase in ocean volume of $+9 \mathrm{~m}$ compared to today would require initially about half the GIS, and subsequently much of the WAIS to change phase, with perhaps a small contribution from the draw-down of the EAIS. A similar stepping up of sea level occurred toward the end of MIS 11 (Hearty et al., 1999; Hearty, 2002b).

The sudden discharge of massive amounts of fresh, cold water capped the oceans, greatly altering the ocean's conveyor belt (Broecker, 1997). With slowed or latitudinally diverted oceanographic circulation in the North Atlantic, temperature gradients temporarily steepened during MIS 5e (Cortijo et al., 1999), with hotter tropics and colder temperate zones, resulting in intense atmospheric clashes and storminess (Neumann and Hearty, 1996; Hearty, 1997; Hearty et al., 1998). It appears that sea level retreated from this position as quickly as it rose to it. 
The retreat was sufficiently rapid that delicate coral structures remained intact on reef crests, rather than being reduced to rubble, as would be the case with slow regression across this zone (Neumann and Hearty, 1996). The speed of sea-level fall implies the synchronous build-up of permanent ice over vast polar regions (Fennoscandia, Laurentia, and alpine regions); including some areas recently laid bare by ice melting and collapse of ice sheets (GIS and WAIS).

The recent evidence for greatly increased flow rates of outlet glaciers (Overpeck et al., 2006) hints at a threshold of GIS stability. If the first half of MIS 5e is a viable analogue for the last $7 \mathrm{ka}$ of the Holocene, as we suggest it is, then we anticipate possible changes in our future that may include of a series of erratic shifts in climate and oceanographic circulation, greater frequency and intensification of storms at subtropical latitudes, eventual GIS melt back, WAIS ice collapse and rapid sea-level rise.

\section{Conclusions}

(1) The geologic and geomorphic record of sea-level changes during MIS 5e reveals intervals of transition and stability. During the early half of the highstand $(\sim 132-125 \mathrm{ka})$, sea level remained relatively stable at $+2.5 \pm 1 \mathrm{~m}$, followed by a minor regression, then rose again to +3 to $4 \mathrm{~m}$. The end of the interglacial period (ca 120-118 ka) was marked by abrupt shifts of sea level between +6 and $+9 \mathrm{~m}$, forming multiple notches and narrow benches. Sea level fell from this late peak into the glacially lowered sea level of MIS 5d. Associated with the end of MIS 5e are oceanographic reorganization, dramatic climate shifts, and intense storminess. The global coherence of our empirical determinations suggests that MIS 5e was far more complex than portrayed in previous models and interpretations. The reconstruction of a more complete sea-level history requires the incorporation of widespread and diverse aspects of coastal stratigraphy, sedimentology, and geomorphology. Restricted sampling and dating of exclusively broad reef tracts evidently yields an incomplete picture of MIS 5e sea level changes.

(2) Our survey of near- to far-field sites on four continents and several oceanic islands yields a coherent story of the relative timing, amplitude, and succession of sealevel events during MIS 5e. The effects of glaciohydroisostasy at near-, intermediate-, and far-field sites on the residual MIS 5e sea-level record are apparently hidden within the uncertainty of measurement.

(3) We attribute the early stable period at +2 to $3 \mathrm{~m}$ to an increased early interglacial contribution from the GIS, compared to today, as suggested by Otto-Bliesner et al. (2006). Late in the interglacial, multiple incised bioerosional notches were formed between +6 and $+9 \mathrm{~m}$. This series of notches provide evidence that sea-level changes occur abruptly and successively, probably associated with ice-sheet collapse. The increased volume of global sea level during MIS 5e requires the partial or complete disintegration of the WAIS. During this time, the North Atlantic experienced a period of intense storminess, large waves, and submergence of low-lying coastal areas.

(4) The abrupt fall of sea level implies a rapid build-up of Northern Hemisphere and perhaps WAIS ice at the end of MIS 5e. "Cold-trap" conditions (higher albedo and dramatic ice build-up caused by perennial snow cover, then ice over vast Arctic areas) and enormous exposed lowland areas all were factors in this catastrophic transition from extreme interglacial highstand to midglacial lowstand conditions in only a few thousand years.

(5) The sea-level stability of the first half of MIS 5e highstand interval is not unlike the previous 6-7 ka of the Holocene. The prolonged stability expressed in the former case ended abruptly in a catastrophic collapse of climate over a period of only a few centuries, and hints at potential future changes in the Holocene.

\section{Acknowledgements}

This study of MIS 5e sea level is the product of more than 20 years of research and collaboration among the authors and others not mentioned. There have been many other persons involved in the development of ideas, analysis of samples, facilitating logistics, and providing support for which we are grateful. The enormous personal, logistical, financial, and academic contributions of $\mathrm{P}$. Kindler, W. Sterrer, J. Sahota, P. and J. Enns, H. and R. DePaolis, and others are recognized and greatly appreciated. S. Olson participated in many of these projects in Hawaii and Bermuda, and sharpened an earlier draft version of this manuscript. Two anonymous reviewers provided constructive comments and reinforced our commitment to the benefits of deciphering sea-level changes through field geology. The primary source of funding was generally out of our collective pockets, but some early studies (Hollin and Hearty's Ph.D.s) were partially supported by US National Science Foundation and other agencies. Our investigations in Bermuda were supported in part by the Bermuda Government, Bermuda Museum, Aquarium and Zoo, and a Queensland-Smithsonian grant, while those in Western Australia were partially funded by The Kanagawa Museum (Australian Academy of Science) and an Australia Research Council Discovery Grant (ID: DP0209059). This is contribution \#127 of the Bermuda Biodiversity Project.

\section{References}

Adkins, J.F., Boyle, E.A., Keigwin, L., Cortijo, E., 1997. Variability of the North Atlantic thermohaline circulation during the Last Interglacial period. Nature 390, 154-156.

Aharon, P., Chappell, J., Compston, W., 1980. Stable isotope and sealevel data from New Guinea supports Antarctic ice-surge theory of ice ages. Nature 283, 649-651. 
Andersen, M.B., Stirling, C.H., Potter, E.K., Halliday, A.N., 2004. Toward epsilon levels of measurement precision on U-234/U-238 by using MC-ICPMS. International Journal of Mass Spectrometry 237 (2-3), 107-118.

Bain, R.J., Kindler, P., 1994. Irregular fenestrae in Bahamian eolianites: a rainstorm-induced origin. Journal of Sedimentary Petrology A 64 (1), 140-146.

Blanchon, P., Eisenhauer, A., 2001. Multi-stage reef development on Barbados during the Last Interglacial. Quaternary Science Reviews 20, 1093-1112.

Blanchon, P., Shaw, J., 1995. Reef drowning during the last deglaciation: evidence for catastrophic sea-level rise and ice-sheet collapse. Geology 23 (1), 4-8.

Bonifay, F., Mars, P., 1959. Le Tyrrhnien dans le cadre de la chronologie quaternaire Mediterrannne. Bulletin Sociologique Francaise 7 (1), $62-78$.

Broecker, W.S., 1997. Thermohaline circulation, the Achilles Heel of our climate system: will man-made $\mathrm{CO}_{2}$ upset the current balance? Science 278, 1582-1588.

Cann, J.H., Clarke, D.A., 1993. The significance of Marginopora vertebralis (Foraminifera) in surficial sediments at Esperance, Western Australia, and in Last Interglacial sediments in northern Spencer Gulf, South Australia. Marine Geology 111, 171-187.

Chappell, J., Veeh, H.H., 1978. Late Quaternary tectonic movements and sea-level changes at Timor and Atauro Island. Geological Society of America Bulletin 89, 356-368.

Chen, J.H., Curran, H.A., White, B., Wasserburg, G.J., 1991. Precise chronology of the Last Interglacial period: $234 \mathrm{U} / 230 \mathrm{Th}$ data from fossil coral reefs in the Bahamas. Geological Society of America Bulletin 103, 82-97.

Cheng, H., Edwards, R.L., Murrell, M.T., Goldstein, S., 1998. The systematics of uranium-thorium-protactinium dating. Geochimica, Cosmochimica Acta 62, 3437-3452.

Cheng, H., Edwards, R.L., Hoff, J., Gallup, C.D., Richards, D.A., Asmerom, Y., 2000. The half-lives of uranium-234 and thorium-230. Chemical Geology 169, 17-33.

Cortijo, E., Lehman, S., Keigwin, L., Chapman, M., Paillard, D., Labeyrie, L., 1999. Changes in meridional temperature and salinity gradients in the North Atlantic Ocean $\left(30^{\circ}-72^{\circ} \mathrm{N}\right)$ during the Last Interglacial period. Paleoceanography 14 (1), 23-33.

Curran, H.A., White, B., (Eds.), 1995. Terrestrial and Shallow marine geology of the Bahamas and Bermuda. Geological Society of America Special Paper 300, 344pp.

Cutler, K.B., Edwards, R.L., Taylor, F.W., Cheng, H., Adkins, J., Gallup, C.D., Cutler, P.M., Burr, G.S., Bloom, A.L., 2003. Rapid sea-level fall and deep-ocean temperature change since the Last Interglacial period. Earth and Planetary Science Letters 206, 253-271.

Dansgaard, W., Johnsen, S.J., Clausen, H.B., Dahl-Jensen, D., Gundestrup, N.S., Hammer, C.U., Hvidberg, C.S., Steffensen, J.P., Svinbjounsdottir, A.E., Jouzel, J., Bond, G., 1993. Evidence for general instability of past climate from a $250 \mathrm{kyr}$ ice core record. Nature 364, 218-220.

Denman, P.D., van de Graaff, W.J.E., 1976. Emergent marine deposits in the Lake MacLeod area, W.A.: Geological Survey of Western Australia. Annual Report, pp. 32-37.

Dumas, B., Hoang, C.-T., Raffy, J., 2006. Record of MIS 5 sea-level highstands based on dated coral terraces of Haiti. Quaternary International 145-146, 106-118.

Dunham, R.J., 1970. Keystone vugs in carbonate beach deposits. Abstract, American Association of Petroleum Geologists Bulletin 54, 845.

Edwards, R.L., Chen, J.H., Ku, T.L., Wasserburg, G.J., 1987. Precise timing of the Last Interglacial period from mass spectrometric determination of thorium-230 in corals. Science 236, $1547-1553$.

Edwards, R.L., Beck, J.W., Burr, G.S., Donahue, D.J., Chappell, J., Bloom, A.L., Duffel, E., Taylor, F., 1993. A large drop in atmospheric
$14 \mathrm{C} / 12 \mathrm{C}$ and reduced melting in the Younger Dryas, documented with 230Th ages of corals. Science 260, 962-968.

Edwards, R.L., Cutler, K.B., Cheng, H., Gallup, C.D., 2003. Geochemical evidence for Quaternary sea-level changes. Treatise on Geochemistry $6,343-364$.

Eggins, S.M., Grün, R., McCulloch, M.T., Pike, A.W.G., Chappell, J., Kinsley, L., Mortimer, G., Shelley, M., Murray-Wallace, C.V., Spötl, C., Taylor, L., 2005. In situ U-series dating by laser-ablation multicollector ICPMS: new prospects for Quaternary geochronology. Quaternary Sciences Reviews 24, 2523-2538.

Fairbridge, R.W., 1953. Australian Stratigraphy. University of Western Australia Press, Nedlands, Western Australia.

Gallup, C.D., Cheng, H., Taylor, F.W., Edwards, R.L., 2002. Direct determination of the timing of sea level change during Termination II. Science 295, 310-313.

Garrett, P., Gould, S.J., 1984. Geology of New Providence Island, Bahamas. Geological Society of America Bulletin 95, 209-220.

Harmon, R.S., Schwarcz, H.P., Ford, D.C., 1978. Late Pleistocene sea level history of Bermuda. Quaternary Research 9, 205-218.

Harmon, R.S., Land, L.S., Mitterer, R.M., Garrett, P., Schwarcz, H.P., Larson, G.J., 1981. Bermuda sea level during the Last Interglacial. Nature 289, 481-483.

Harmon, R.S., Mitterer, R.M., Kriausakul, N., Land, L.S., Schwarcz, H.P., Garrett, P., Larson, G.J., Vacher, H.L., Rowe, M., 1983. $\mathrm{U} / \mathrm{Th}$ and amino acid racemization geochronology of Bermuda: implications for eustatic sea-level fluctuation over the past 250,000 years. Paleogeography, Paleoclimatology, Paleoecology 44, $41-70$.

Hearty, P.J., 1986. An inventory of Last Interglacial (sl.) age deposits from the Mediterranean basin: a study in isoleucine epimerization and $\mathrm{U} / \mathrm{Th}$ dating. Zeitschrift für Geomorphologie, Supplement Band 62, 51-69.

Hearty, P.J., 1987. New data on the Pleistocene of Mallorca. Quaternary Science Reviews 6, 245-257.

Hearty, P.J., 1997. Boulder deposits from large waves during the Last Interglaciation on North Eleuthera, Bahamas. Quaternary Research 48, 326-338.

Hearty, P.J., 1998. The geology of Eleuthera Island, Bahamas: a Rosetta Stone of Quaternary stratigraphy and sea-level history. Quaternary Science Reviews 17, 333-355.

Hearty, P.J., 2002a. A revision of the late Pleistocene stratigraphy of Bermuda. Sedimentary Geology 153 (1-2), 1-21.

Hearty, P.J., 2002b. The Kaena highstand on Oahu, Hawaii: further evidence of Antarctic Ice collapse during the middle Pleistocene. Pacific Science 56 (1), 65-82.

Hearty, P.J., 2003. Stratigraphy and ages of fossil carbonate deposits of Rottnest Island, Western Australia. Quaternary Research 60, 211-222.

Hearty, P.J., Aharon, P., 1988. Amino acid chronostratigraphy of late Pleistocene coral reef sites: Huon Peninsula, New Guinea and the Great Barrier Reef, Australia. Geology 16 (7), 79-583.

Hearty, P.J., Dai Pra, G., 1986. Aminostratigraphy of Quaternary marine deposits in the Lazio region of central Italy. Zeitschrift für Geomorphologie, Supplement Band 62, 131-140.

Hearty, P.J., Dai Pra, G., 1992. The age and stratigraphy of Quaternary coastal deposits along the Gulf of Taranto (South Italy). Journal of Coastal Research 8 (4), 882-905.

Hearty, P.J., Kaufman, D.S., 2000. Whole-rock aminostratigraphy and Quaternary sea-level history of the Bahamas. Quaternary Research 54, 163-173.

Hearty, P.J., Kindler, P., 1993a. An illustrated stratigraphy of the Bahamas: in search of a common origin. Bahamas Journal of Science 1 (1), 28-45.

Hearty, P.J., Kindler, P., 1993b. New perspectives on Bahamian geology: San Salvador Island, Bahamas. Journal of Coastal Research 9 (2), 577-594.

Hearty, P.J., Kindler, P., 1995. Sea-level highstand chronology from stable carbonate platforms (Bermuda and the Bahamas). Journal of Coastal Research 11 (3), 675-689. 
Hearty, P.J., Kindler, P., 1997. The stratigraphy and surficial geology of New Providence and surrounding islands, Bahamas. Journal of Coastal Research 13 (3), 798-812.

Hearty, P.J., Neumann, A.C., 2001. Rapid sea-level and climate change at the close of the Last Interglaciation (MIS 5e): evidence from the Bahama Islands. Quaternary Science Reviews 20, 1881-1895.

Hearty, P.J., Miller, G.H., Stearns, C., Szabo, B.J., 1986. Aminostratigraphy of Quaternary shorelines around the Mediterranean basin. Geological Society of America Bulletin 97, 850-858.

Hearty, P.J., Hollin, J.T., Dumas, B., 1987. Geochronology of Pleistocene littoral deposits on the Alicante and Almeria coasts of Spain. In: Zazo, C. (Ed.), Late Quaternary Sea Level Changes in Spain. Trab. Neogeno-Cuaternario, vol. 10, pp. 95-105.

Hearty, P.J., Vacher, H.L., Mitterer, R.M., 1992. Aminostratigraphy and ages of Pleistocene limestones of Bermuda. Geological Society of America Bulletin 104, 471-480.

Hearty, P.J., Neumann, A.C., Kaufman, D.S., 1998. Chevron ridges and runup deposits in the Bahamas from storms late in oxygen isotope substage 5e. Quaternary Research 50, 309-322.

Hearty, P.J., Kindler, P., Cheng, H., Edwards, R.L., 1999. $\mathrm{A}+20 \mathrm{~m}$ middle Pleistocene sea-level highstand (Bermuda and the Bahamas) due to partial collapse of Antarctic ice. Geology 27, 375-378.

Hearty, P.J., Kaufman, D.S., Olson, S.L., James, H.F., 2000. Stratigraphy and whole-rock amino acid geochronology of key Holocene and Last Interglacial carbonate deposits in the Hawaiian Islands. Pacific Science 54 (4), 423-442.

Hearty, P.J., O’Leary, M.J., Donald, A., Allayialis, D., 2004. Stratigraphy and geochronology of Quaternary carbonate and quartz dunes of Western Australia. In: Proceedings of the 17th Australian Geological Convention, Hobart, Tasmania, February 2004.

Hearty, P.J., James, H., Olson, S.L., 2005. The geological context of paleo-lakes and Pleistocene birds at Ulupau Head, O'ahu, Hawaiian Islands, pp. 113-128. In: Alcover, J.A., Bover, P. (Eds.), Insular Vertebrate Evolution: the Palaeontological Approach. Monografies de la Societat d'Història Natural de les Balears, September 2003, Mallorca, Spain, 390pp.

Hearty, P.J., O'Leary, M.J., Neumann, A.C., 2007. Comment on “Record of MIS 5 sea-level highstands based on U/Th dated coral terraces of Haiti” (B. Dumas, C.T. Hoang, and J. Raffy, 2006, Quaternary International, 145-146, 106-118). Quaternary International 162-163, 205-208.

Herm, D., Paskoff, R., Sanlaville, P., 1980. La stratigraphie des falaises d'Hergla (Sahel del Sousse, Tunisie) et son importance pour la comprehension du Quaternarire marin recent de la Tunisie. Comptes Rendus Sommaire de Societe Geologique Francaise 1, 25-28.

Hewgill, F.R., Kendrick, G.W., Webb, R.J., Wyrwoll, K-H., 1983. Routine ESR dating of emergent Pleistocene marine units in Western Australia. Search 14, 215-217.

Hoang, C-T., Hearty, P.J., 1989. A comparison of geochronological methods from the "Il Fronte Formation," Puglia, Italy and Son Grauet, Mallorca, Spain. Isotope Geoscience 79 (4), 317-323.

Hollin, J.T., 1962. On the glacial history of Antarctica. Journal of Glaciology 4, 173-195.

Hollin, J.T., 1977. Thames interglacial sites, Ipswichian sea levels and Antarctic ice surges. Boreas 1, 33-52.

Hollin, J.T., 1982. Rapid transgressions and coolings in isotope stage 5. In: American Quaternary Association Seventh Biennial Conference, Program and Abstracts, pp. 44-46.

Hollin, J.T., Hearty, P.J., 1990. South Carolina interglacial sites and stage 5 sea levels. Quaternary Research 33, 1-17.

Kaufman, A., Broecker, W.S., Ku, T.L., Thurber, D.L., 1971. The status of U/Th methods of mollusc dating. Geochemica Cosmochemica Acta $35,1155-1183$.

Kaufman, A., Ghaleb, B., Wehmiller, J.F., Hillaire-Marcel, C., 1996. Uranium concentration and isotope ratio profiles within Mercenaria shells: geochronological implications. Geochimica et Cosmochimica Acta $60,3735-3746$.
Kendrick, G.W., Wyrwoll, K-H., Szabo, B.J., 1991. Pliocene-Pleistocene coastal events and history along the western margin of Australia. Quaternary Science Reviews 10, 419-439.

Kindler, P., Hearty, P.J., 1996. Carbonate petrology as an indicator of climate and sea-level changes: new data from Bahamian Quaternary units. Sedimentology 43 (2), 381-399.

Kindler, P., Hearty, P.J., 1997. Geology of the Bahamas: architecture of Bahamian Islands. In: Vacher, H.L., Quinn, T. (Eds.), Geology and Hydrogeology of Carbonate Islands, Developments in Sedimentology, vol. 54. Elsevier, Amsterdam, pp. 141-160.

Kindler, P., Davaud, E., Strasser, A., 1997. Tyrrhenian coastal deposits from Sardinia (Italy): a petrographic record of high sea levels and shifting climate belts during the Last Interglacial (isotope substage 5e). Palaeogeography, Palaeoclimatology, Palaeoecology 133, 1-25.

Ku, T.L., Kimmel, M.A., Easton, W.H., O'Neill, T.J., 1974. Eustatic sea level 120,000 years ago on Oahu, Hawaii. Science 183, 959-962.

Ku, T.L., Ivanovitch, M., Luo, S., 1990. U-series dating of Last Interglacial high sea stands: Barbados revisited. Quaternary Research 33, 129-147.

Kukla, G., McManus, J.F., Rousseau, D.-D., Chuine, I., 1997. How long and stable was the Last Interglacial. Quaternary Science Reviews 16, 605-612.

Lambeck, K., Nakada, M., 1992. Constraints on the age and duration of the Last Interglacial period and on sea-level variations. Nature 357, 125-128.

Land, L.S., Mackenzie, F.T., Gould, S.J., 1967. The Pleistocene history of Bermuda. Geological Society of America Bulletin 78, 993-1006.

Lighty, R.G., Macintyre, I.G., Stuckenrath, R., 1982. Acropora palmata reef framework: a reliable indicator of sea level in the Western Atlantic for the past 10,000 years. Coral Reefs 1, 125-130.

Linsley, B.K., 1996. Oxygen-isotope record of sea level and climate variations in the Sulu Sea over the past 150,000 years. Nature 380, 234-237.

Ludwig, K.R., Muhs, D.R., Simmons, K.R., Halley, R.B., Shinn, E.A., 1996. Sea-level records at $\sim 80$ ka from tectonically stable platforms: Florida and Bermuda. Geology 24 (3), 211-214.

McCulloch, M.T., Esat, T., 2000. The coral record of Last Interglacial sea levels and sea surface temperatures. Chemical Geology 169, 107-129.

McGowran, B., Li, Q., Cann, J., Padley, D., McKirdy, D.M., Shafik, S., 1997. Biogeographic impact of the Leeuwin Current in southern Australia since the late middle Eocene. Palaeogeography, Palaeoclimatology, Palaeoecology 136, 19-20.

Meischner, D., Vollbrecht, R., Wehmeyer, D., 1995. Pleistocene sea-level yo-yo recorded in stacked beaches, Bermuda South Shore. Geological Society of America Special Paper \#300, pp. 295-310.

Mercer, J.H., 1978. West Antarctic ice sheet and $\mathrm{CO}_{2}$ greenhouse effect: a threat of disaster. Nature 271, 321-325.

Mesolella, K.J., Matthews, R.K., Broecker, W.S., Thurber, D.L., 1969. The astronomical theory of climate change: Barbados data. Journal of Geology 77, 250-274.

Miller, G.H., Stearns, C.E., Paskoff, R., 1986. Amino acid geochronology of Pleistocene littoral deposits in Tunisia. Zeitschrift für Geomorphologie, Supplement Band 62, 197-207.

Mitterer, R.M., 1974. Pleistocene stratigraphy in southern Florida based on amino acid diagenesis in fossil Mercenaria. Geology 2, 425-428.

Mitterer, R.M., 1975. Ages and diagenetic temperatures of Pleistocene deposits of Florida based on isoleucine epimerization in Mercenaria. Earth and Planetary Science Letters 28, 275-282.

Muhs, D.R., Szabo, B.J., 1994. New uranium-series ages of the Waimanalo Limstone, Oahu, Hawaii: Implications for sea level during the Last Interglacial period. Marine Geology 118, 315-326.

Muhs, D.R., Bush, C.A., Stewart, K.C., Rowland, T.R., Crittenden, R.C., 1990. Geochemical evidence of Saharan dust on Quaternary limestones of Caribbean and western Atlantic Islands. Quaternary Research 33, 157-177.

Muhs, D.R., Simmons, K.R., Steinke, B., 2002. Timing and warmth of the Last Interglacial period: new U/Th evidence from Hawaii and 
Bermuda and a new fossil compilation for North America. Quaternary Sciences Reviews 21, 1355-1383.

Munsell, 2001. Soil Color Charts, 2001 (revised ed.). Macbeth Division of Kollmorgan Instruments Corporation, New Windsor, NY.

Murray-Wallace, C., Belperio, A.P., 1991. The Last Interglacial shoreline in Australia - a review. Quaternary Science Reviews 10, 441-461.

Murray-Wallace, C.V., Kimber, R.W.L., 1989. Quaternary marine aminostratigraphy: Perth Basin, Western Australia. Australian Journal of Earth Sciences 36, 553-568.

Murray-Wallace, C.V., Brooke, B.P., Cann, J.H., Belperio, A.P., Bourman, R.P., 2001. Whole-rock aminostratigraphy of the Coorong, Coastal Plain, South Australia: towards a 1 million year record of sealevel highstands. Journal of the Geological Society of London 158, $111-124$.

Neumann, A.C., 1965. Observations on coastal erosion in Bermuda and measurements of the boring rate of the sponge Cliona lampa. Limnology and Oceanography 11 (1), 92-108.

Neumann, A.C., Hearty, P.J., 1996. Rapid sea-level changes at the close of the Last Interglacial (stage 5e) recorded in Bahamian Island geology. Geology 24, 775-778.

Neumann, A.C., Moore, W.S., 1975. Sea level events and Pleistocene coral ages in the northern Bahamas. Quaternary Research 5, 215-224.

Neumann, A.C., MacIntyre, I., 1985. Reef response to sea level rise: keepup, catch-up or give-up. In: Proceedings of Fifth International Coral Reef Congress, Tahiti, vol. 3, pp. 105-110.

Nicklés, M., 1950. In: Lechevalier, P. (ed.), Mollusques testaces Marins de la côte occidentale d'Afrique, Paris.

O'Leary, M.J., 2007. The stratigraphy and geochronology of emergent fossil reef deposits of Western Australia. Unpublished Ph.D. Thesis, James Cook University, Australia, 130pp.

Oppenheimer, M., 1998. Global warming and the stability of the West Antarctic ice sheet. Nature 393, 325-332.

Otto-Bliesner, B.L., Marshall, S.J., Overpeck, J.T., Miller, G.H., Hu, A., 2006. CAPE Last Interglacial project members. Science 311, 1751-1753.

Overpeck, J.T., Otto-Bliesner, B.L., Miller, G.H., Muhs, D.R., Alley, R.B., Kiehl, J.T., 2006. Paleoclimatic evidence for future ice-sheet instability and rapid sea-level rise. Science $311,1747-1750$.

Playford, P.E., 1988. Guidebook to the geology of Rottnest Island: Geological Society of Australia. Western Australia Division and Geological Survey, Guidebook no. 2, pp. 67.

Riccio, A., Riggio, F., Romano, P., 2001. Sea level fluctuations during Oxygen Isotope Stage 5: new data from fossil shorelines in the Sorrento Peninsula (Southern Italy). Zeitschrift fur Geomorphologie N.F. 45 (1), 121-137.

Robinson, L.F., Belshaw, N.S., Henderson, G.M., 2004. U and Th concentrations and isotope ratios in modern carbonates and waters from the Bahamas. Geochimica et Cosmochimica Acta 68, 1777-1789.

Schellmann, G., Radtke, U., 2004. The Marine Quaternary of Barbados. Kölner Geographische Arbeiten, vol. 81. Geographisches Institut der Universität zu Köln, Heft, 137pp.

Seidenkrantz, M.-S., Knudsen, K.L., 1994. Foraminiferal evidence of a short-term cold period during the Last Interglacial at Skagen, Denmark: AMQUA Abstracts: 157.

Shackleton, N.J., 1987. Oxygen isotopes, ice volume and sea level. Quaternary Science Reviews 6, 183-190.
Sherman, C.E., Glenn, C.R., Jones, A.T., Burnett, W.C., Schwarcz, H.P., 1993. New evidence for two highstands of the sea during the Last Interglacial, oxygen isotope substage 5e. Geology 21, 1079-1082.

Sirocko, F., Seelos, K., Schaber, K., Rein, B., Dreher, F., Diehl, M., Lehne, R., Jager, K., Krbetschek, M., Degering, D., 2005. A late Eemian aridity pulse in central Europe during the last glacial inception. Nature 436, 833-836.

Spencer, T., 1992. Bioerosion and biogeomorphology. In: John, D.M., et al. (Eds.), Plant-animal interactions in the marine benthos. Systematics Association Special Volume 46, Oxford, Clarendon Press, pp. 493-509.

Spencer, T., Viles, H., 2002. Bioconstruction, bioerosion, and disturbance on coral reefs and rocky carbonate coasts. Geomorphology 48, 23-50.

Stearns, H.T., 1978. Quaternary shorelines in the Hawai'ian Islands. B.P. Bishop Museum Bulletin 237, 1-57.

Stearns, C.E., 1984. Uranium-series dating and the history of sea level. In: Mahaney, W.C. (Ed.), York University Symposium on Dating Methods. Amsterdam.

Stirling, C.H., Esat, T.M., McCulloch, M.T., Lambeck, K., 1995. Highprecision U-series dating of corals from Western Australia and implications for the timing and duration of the Last Interglacial: Earth Planet. Science Letters 135, 115-130.

Stirling, C.H., Esat, T.M., Lambeck, K., McCulloch, M.T., 1998. Timing and duration of the Last Interglacial: evidence for a restricted interval of widespread coral reef growth. Earth and Planetary Science Letters $160,745-762$.

Szabo, B.J., Ludwig, K.R., Muhs, D.R., Simmons, K.R., 1994. Thorium230 ages of corals and duration of the Last Interglacial sea-level high stand on Oahu, Hawaii. Science 266, 93-96.

Thompson, W.G., Goldstein, S.L., 2005. Open-system coral ages reveal persistent suborbital sea-level cycles. Science 308 (5720), 401-404.

Tu, X., Zheng, F., Wang, J., Cai, H., Wang, P., Buhring, C., Sarnthein, M., 2001. An abrupt cooling event early in the Last Interglacial in the northern South China Sea. Science in China 44 (10), $865-870$.

Ulzega, A., Hearty, P.J., 1986. Geochronology of Sardinian shoreline deposits. Zeitschrift fur. Geomorphologie, Supplement Band 62, $119-130$.

Vacher, H.L., Rowe, M., Garrett, P., 1989. Geologic map of Bermuda: Oxford Cartographers, UK 1:25,000 scale.

Vacher, H.L., Hearty, P.J., Rowe, M., 1995. Stratigraphy of Bermuda: Nomenclature, Concepts, and status of multiple systems of classification. In: Curran, H.A., White, B. (Eds.), Terrestrial and Shallow Marine Geology of the Bahamas and Bermuda. Geological Society of America Special Paper no. 300, pp. 271-294.

Veeh, H.H., Schwebel, D., van de Graaff, W.J.E., Denman, P.D., 1979. Uranium-series ages of coralline terrace deposits in Western Australia. Journal of the Geological Society of Australia 26, 285-292.

Wentworth, C.K., Hoffmeister, J.E., 1939. Geology of Ulupau Head, Oahu. Geological Society of America Bulletin 50, 1553-1572.

White, B., Curran, H.L., Wilson, M.A., 1998. Bahamian coral reefs yield evidence of a brief sea-level lowstand during the Last Interglacial. Carbonates and Evaporites 13 (1), 10-22.

Woillard, G., 1979. Abrupt end of the Last Interglacial s.s. in north-east France. Nature 281, 558-562. 